


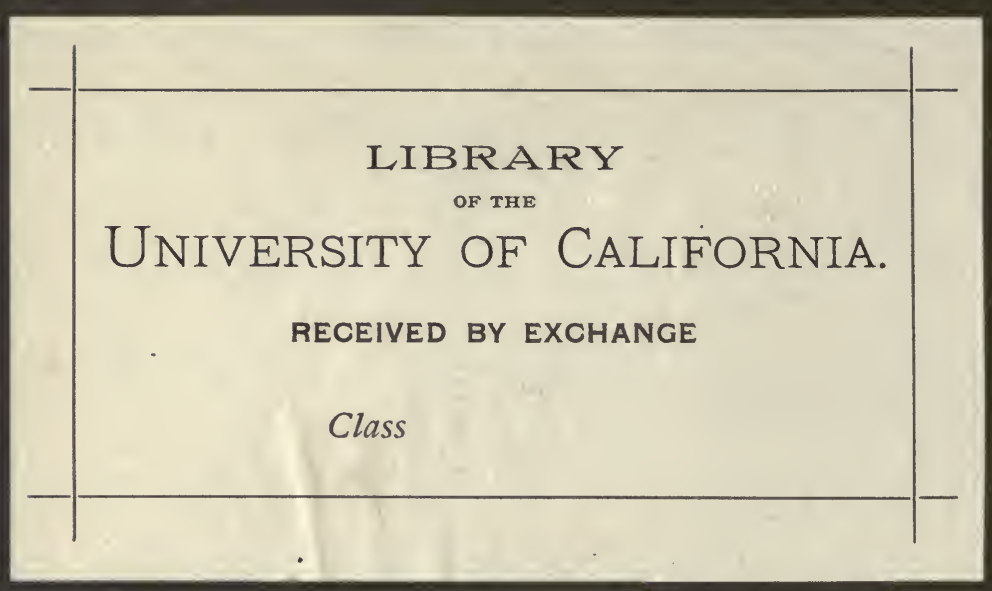




\title{
AN APPLE ORCHARD SURVEY OF
}

NIAGARA COUNTY NEW YORK

\begin{abstract}
A THESIS
Presented to the Faculty of The Graduate School, OF CORNELI, UNIVERSITY FOR THE DEGREE OF DOCTOR OF PHILOSOPHY
\end{abstract}

BY

MARSHALL, BAX'TER CUMMINGS

[Reprinted from Bulletin 262, Cornell University Experiment Station.] 


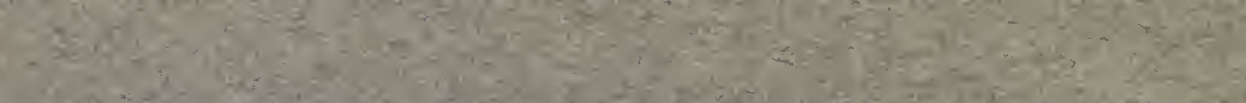

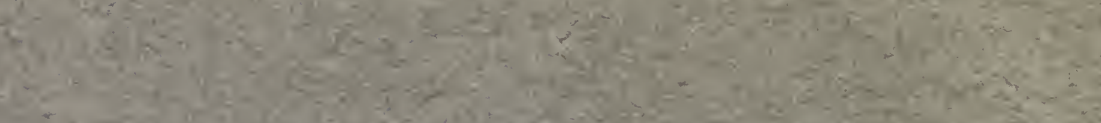

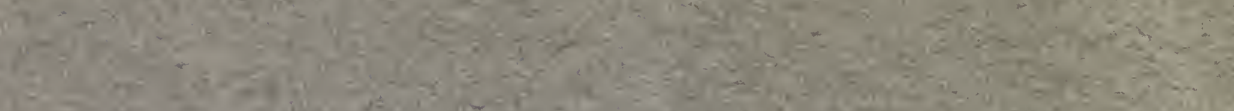

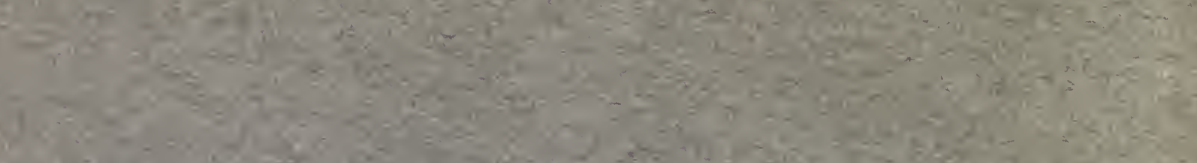

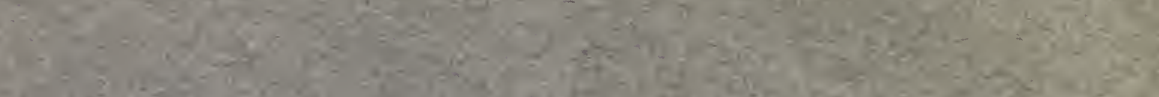

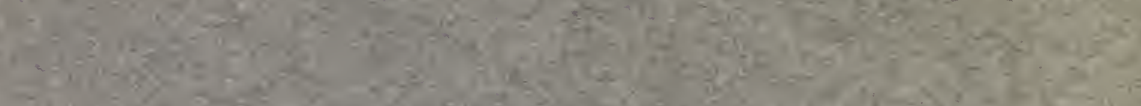

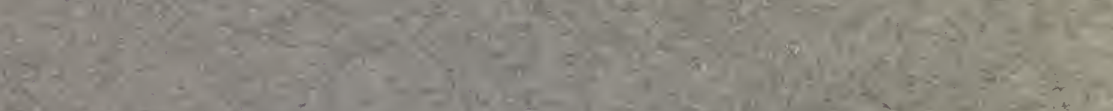

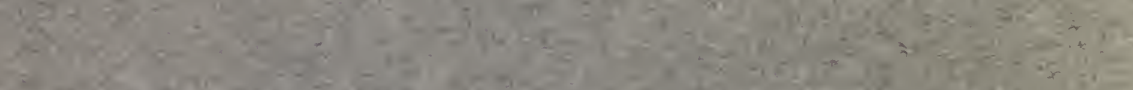

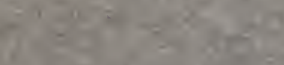

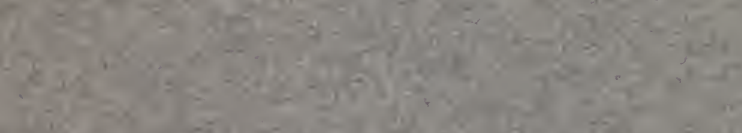
$\lim _{x \rightarrow 1}=\frac{5}{4}$ (2)

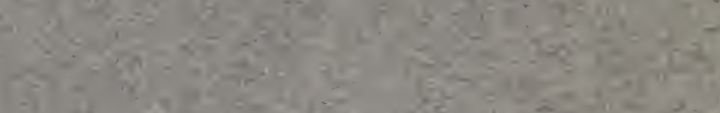
$\infty$ 


\section{CORNELL UNIVERSITY}

AGRICULTURAL EXPERIMENT STATION OF

THE COLLEGE OF AGRICULTURE

Department of Horticulture

\section{APPLE ORCHARD SURVEY OF}

NIAGARA COUNTY

Under the Direction of

JOHN CRAIG

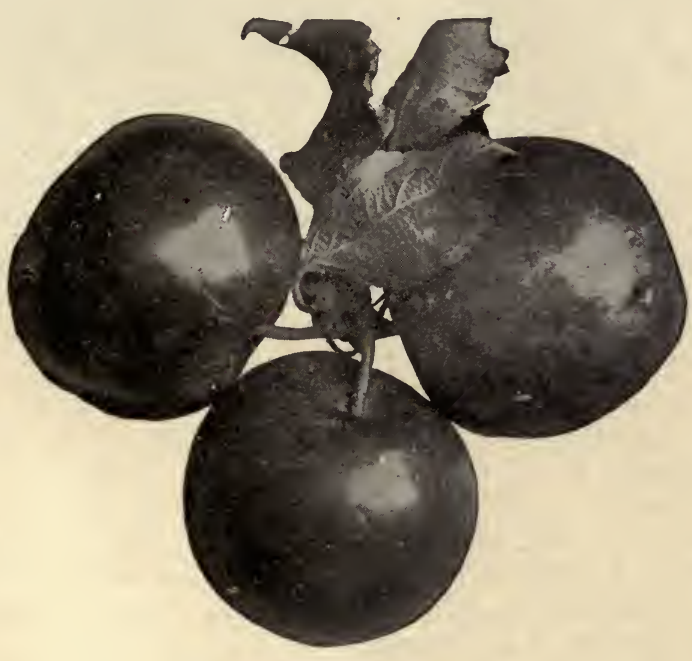

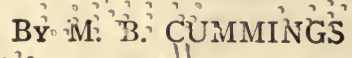

0

ITHACA, N. Y.

PUBLISHED BY THE UNIVERSITY 


\section{ORGANIZATION}

Of The Cornell University Agricultural Experiment

Station.

BOARD OF CONTROL

THE TRUSTEES OF THE UNIVERSITY

the agricultural COLlege and station Council

JACOB GOULD SCHURMAN, President of the University.

ROBERT H. TREMAN, Trustee of the University.

LIBERTY H. BAILEY, Director of the College and Experiment Station.

EMMONS L. WILLIAMS, Treasurer of the University.

JOHN H. COMSTOCK, Professor of Entomology.

HENRY H. WING, Professor of Animal Husbandry.

EXPERIMENTING STAFF

LIBERTY H. BAILEY, Director.

JOHN HENRY COMSTOCK, Entomology.

HENRY H. WING, Animal Husbandry.

JOHN CRAIG, Horticulture.

T. LYTTLETON LYON, Soil Investigations.

H. J. WEBBER, Plant-Breeding.

B. M. DUGGAR, Plant Physiology.

JOHN L. STONE, Farm Practice.

JAMES E. RICE, Poultry Husbandry.

MARK V. SLINGERLAND, Entomology.

GEORGE W. CAVANAUGH, Chemistry.

ELMER O. FIPPIN, Soils.

W. A. STOCKING, Jr., Dairy Bacteriology.

HERBERT H. WHETZEL, Plant Pathology.

G. F. WARREN, Farm Crops.

LOWELL B. JUDSON, Horticulture.

CHARLES S. WILSON, Horticulture.

M. W. HARPER, Animal Husbandry.

CHARLES F. CLARK, Agronomy.

JAMES A. BIZZELL, Seil Investigations.

C. A. PUBLOW, Dairy Industry.

CYRUS R. CROSBY, Entomology.

C. A. ROGERS, Poultry Husbandry.

P. J. WHITE, Farm Crops.

D. REDDICK, Plant.Pathology : : : :

E. R. MINNS, Farm Fractice ${ }^{\circ}: \because::^{\circ}$

G. A. CRABB, Soils.

E. S. GUTHRLE, Butternakng $: \therefore$.

M. F. BARRUS, Plant Pathology

M. B. CUMMINGS, Horticulture.

The regular bulletins of the Station are sent free to persons residing in New York State who request them. 


\section{Apple Orchard Survey of Niagara County*}

\section{INTRODUCTION}

\section{By John CRAIG}

The active campaign was commenced in July, I905, by the writer, assisted by Messrs. C. S. Wilson and G. W. Hosford. The first orchard examined was the peach orchard of the late Dr. Charles A. Ring on the Lake Road. Dr. Ring was a prime agitator for the institution of this work in Niagara County and extended the hospitality of his home for more than a week to the three persons who began the work. Other

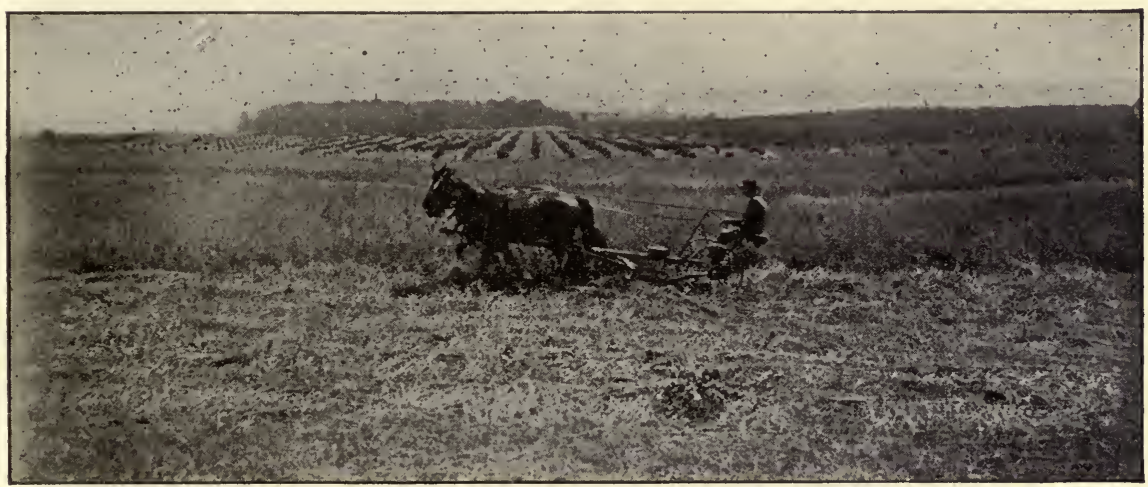

FIG. 26.-A general view of the topography of the Lake Road region, Niagara County

persons who kindly aided the survey in the same way in order to economize funds, were Messrs. W. T. Mann, L. and Frank Bradley of Barkers; S. W. McCollum and F. R. Wheeler of Lockport. Kindly coöperation was also rendered by Albert Eighme, George Pomeroy, Willard Hopkins, Frank Hall, Frank Balmer and John Witmer. Indeed, the fruit growers of the county generally should be thanked for the generous way in which they responded to our requests for data and general information.

The following orchard inspectors were employed during the seasons of 1905 and 1906: Messrs. J. E. Coit, C. D. Jarvis, J. E. Howitt, C. F. Kinman, J. P. Stewart, C. F. and L. A. Niven. The work was finally completed by the author of this bulletin, M. B. Cummings, in 1907.

* Printed January, 1909, but withdrawn for reëxamination of statistics. Revised and reprinted for distribution May, 19ro.-J. C. 
Cooperation by the Bureau of Soils. At the inception of the orchard examination, the desirability of adding to its completeness by securing a survey of soil conditions was immediately recognized. The matter was presented to the Chief of the Bureau of Soils through whose kind coöperation a soil survey was authorized and completed in the summer of I906 under the immediate direction of Professor E. O. Fippin. The full text of this examination is set forth in the eighth Report of the Field Operations of the Bureau of Soils, I906, pages 69 to I I7. Copies of the bound volumes of the soil survey are on sale by the Superintendent of Documents, Government Printing Office, Washington, D. C. Separate copies of soil surveys may be secured by applying to the Bureau of Soils, except when the supply is exhausted.

\section{HISTORICAL NOTES}

In I779, a large tract of country in the western part of New York was set off and styled Ontario. This embraced the entire region lying between the two lakes, including Steuben, Ontario, Yates, Allegany, Cattaraugus, Livingston, Chautauqua, Erie, Orleans, Wyoming, Genesee, Wayne, Monroe and Niagara Counties. The subdivisions which erected these counties were made between I779 and 1854, Niagara being separated from the group in 1808 . At this time, Buffalo was little more than a village, Niagara County mostly in timber, and the old Ridge Road unopened.

Fruit-growing has been associated with the progress of this county from its earliest settlement. It is recorded that Indian orchards existed here in the regions occupied by the Senecas and the Oneidas. The Sullivan expedition against the warlike tribes in western New York in I779, caused the destruction of thousands of fruit trees. Miss Stites, the author of the "Economics of the Iroquois," says:

"The apple is the Iroqouis banana. From the earliest introduction of this fruit into New York and into New France from the genial plains of Holland and Normandy, these tribes appear to have been captivated by its taste and they lost no time in transferring it, by sowing the seed, to the sites of their ancient castles. No one can read the accounts of the destruction of their extensive orchards of the apple, which were cut down on General Sullivan's inroad into the Genesee country in 1779, without regretting that the purposes of war should require this barbaric act. The Census (of Schoolcraft) will show that this taste remains as strong in 1845 as it was sixty-six years ago. Upwards of four thousand fruit trees were counted in the Senecas' territory alone 
(1845), and the Tuscaroras (this tribe occupied the present site of $\mathrm{Ni}$ agara County) had over fifteen hundred fruit trees."

Apple-orcharding.-Apple-tree planting in Niagara County began, as it did in New England and the older states, by first setting out seedling trees. Many of these were subsequently top-grafted. There were practically three eras in the apple-orcharding history of western New York: First, the era of seedling apples; second, the era of top-grafting, when these were worked over to named varieties from New England; and

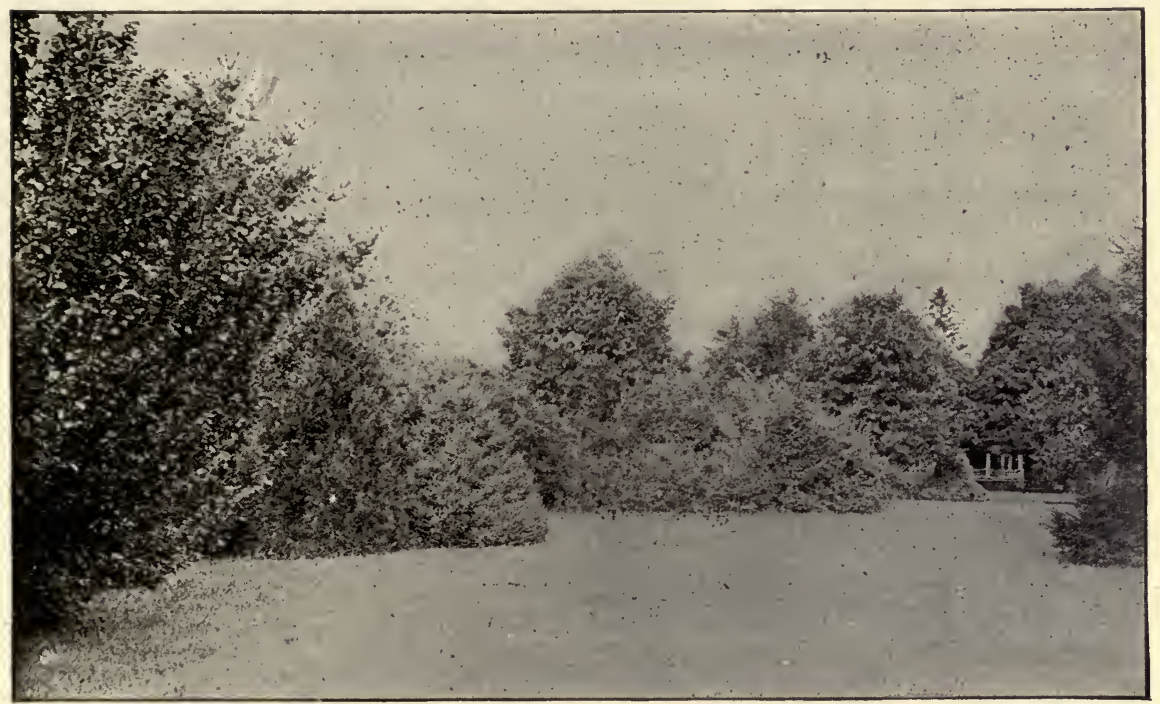

FIG. 27.-A part of the lawn surrounding the residence of Mr.W.T. Mann

third, the era which marked the establishment of the great commercial orchards of today, and the planting of Greening, Baldwin, Spy; and the like.

Early murseries. - It is recorded in Turner's history of Niagara County (1878, page 232) that in I8I3, one Jairus Rose, living near Sanborn, sowed two acres of land to apple seed, thus starting the first nursery in the county. The young trees were distributed throughout the settled parts of the county. The price of these seedling trees was twelve cents each. It would be very interesting to know whether this distribution of seedlings did not give rise to some important local varieties peculiar to western New York.

Among other nurseries established was that of Dr. William Townshend, near Lockport, about I830. S. Cudaback and Timothy Outwater 
maintained a nursery on the Lake Road between Wilson and Olcott about the same time.

In 1839, Elisha Moody established a nursery on the Ridge Road northeast of Lockport. The founder was the first president of the American Association of Nurserymen. The original firm has been continued by E. Moody \& Sons now in business at Lockport.

Messrs. Penfield and Burrell, of Lockport, were also in business between 1850 and 1865 , at the time when there was considerable activity in the planting of orchards. To these early nurserymen the county is largely indebted for the large commercial orchards now in bearing.

\section{VALUABLE FRUITS ORIGINATING IN NIAGARA COUNTY}

Niagara County has given to the State and the Nation some valuable varieties of fruit. The varieties noted below include only those which are of more than local significance.

Niagara peach.-Like many good things, there is some obscurity as to the origin of this peach. Two men in the town of Newfane, this county (Niagara), claim its discovery, but the most probable story of its origin is given as follows by J. S. Woodward, Lockport:

"Fifteen or more years ago, Mr. P. H. Corwin began to grow peach trees for sale in a small way. In an orchard of Early Crawford from which he was taking buds, he noticed a very vigorous tree that bore very nice large peaches, and naturally he cut a good many buds from this tree. When the trees he sold began to bear, the owner noticed a marked difference in the fruit on different trees and made inquiry of Mr. Corwin as to the cause. This led to close inspection of the orchard from which the buds had been cut and established the fact that there was a variety very distinct from Early Crawford. In I894, Mr. Corwin began to propagate this as a new sort, and at first called it Mammoth Crawford; but as this would lead to a confusion of names, Niagara was substituted and today it is known by no other name. The tree is a more vigorous grower, with heavier and darker green leaves and more stocky wood than the Crawford; nor does it load on as much fruit as the Crawford at its best. It begins to ripen about one picking later than Crawford, and the fruit is larger, more round and of better quality than the Crawford and holds out good in size to the last. Anyone going through an orchard of Crawfords with a few Niagaras mixed in, has no difficulty in distinguishing the variety even when there is no fruit on the trees."

Niagara grape.- The Niagara white grape is one of the leading commercial grapes of the state. It originated in 1872 with the nursery firm of Hoag and Clark of Lockport, N. Y. It is the product of a cross of Concord and Cassidy described as follows by the originators: 
Hardy, healthy, vigorous and productive; wood rather long jointed; leaves large, thick, leathery and downy, often double-lobed; bunch medium to large, 8 to 14 ounces in weight, compact and often shouldered; berry large, roundish to oval, uniform in size, with tough but thin skin, pale green changing to yellow when fully ripe; flesh soft, tender, sweet and pleasant, and of good quality. This grape has attained a permanent place as the leading white grape of Ohio, New Jersey and New York, and is extensively planted in the grape districts of central and western New York.

Somerset apple. - The Somerset is reported as having originated in the town of Somerset. It was first brought to notice by C. L. Hoag of Lockport. Somerset is an early apple of sprightly flavor, and considered good for family use. The fruit is somewhat below medium, roundish conical in shape and of a deep golden-yellow color. The flesh is nearly white, tender, juicy, with a rich aromatic flavor. The quality is very good. The tree is upriglit and spreading in its growth. Somerset is especially noted for its earliness. It is said to be very productive.

Pomeroy English walnuts.-These were introduced into Niagara County in 1876 . Norman Pomeroy brought several walnuts home with him from the Centennial at Philadelphia and planted them in his garden in Lockport. From these native-grown nuts he raised a number of trees. Several varieties were obtained, and the best one was named by H. E. VanDeman the Pomeroy walnut. This variety has proved hardy and productive, and each year the nuts are saved for nursery. plantings. A. C. Pomeroy is now in charge of the walnut nursery.

\section{THE OUTLOOK}

That this is encouraging, there is no question whatever. The progressive, prudent apple grower of Niagara County should be, and is, prosperous. Notable examples of successes by men who engaged in the business under exceedingly unfavorable circumstances are not rare. When failure has occurred, it may usually be charged to one or all of the following causes: lack of capital, enterprise or knowledge, and extensive rather than intensive efforts. The bane of many beginners is insufficiency of capital, but this is not so fatal as inadequate knowledge. Then, many beginners develop too rapidly. A slow, steady growth is much better than a rapid, unhealthy growth. Niagara County possesses substantial natural advantages for growing fine apples. Much of the soil is admirably adapted, the climate is favorably tempered by proximity to Lake Ontario. A large and growing market is near at hand, while the transportation facilities are much better than the average. 
What, then, is needed? Better care of existing orchards; renovation of some orchards declining under present management; the planting of new orchards with high-grade varieties and their cultivation after the most approved methods; and, finally, picking, packing and marketing the fruit in a thoroughly business-like manner.

The new apple regions of the Northwest Pacific are successfully competing, and in some degree securing the cream of the returns in the markets of the east. There is no question in regard to the innate ability

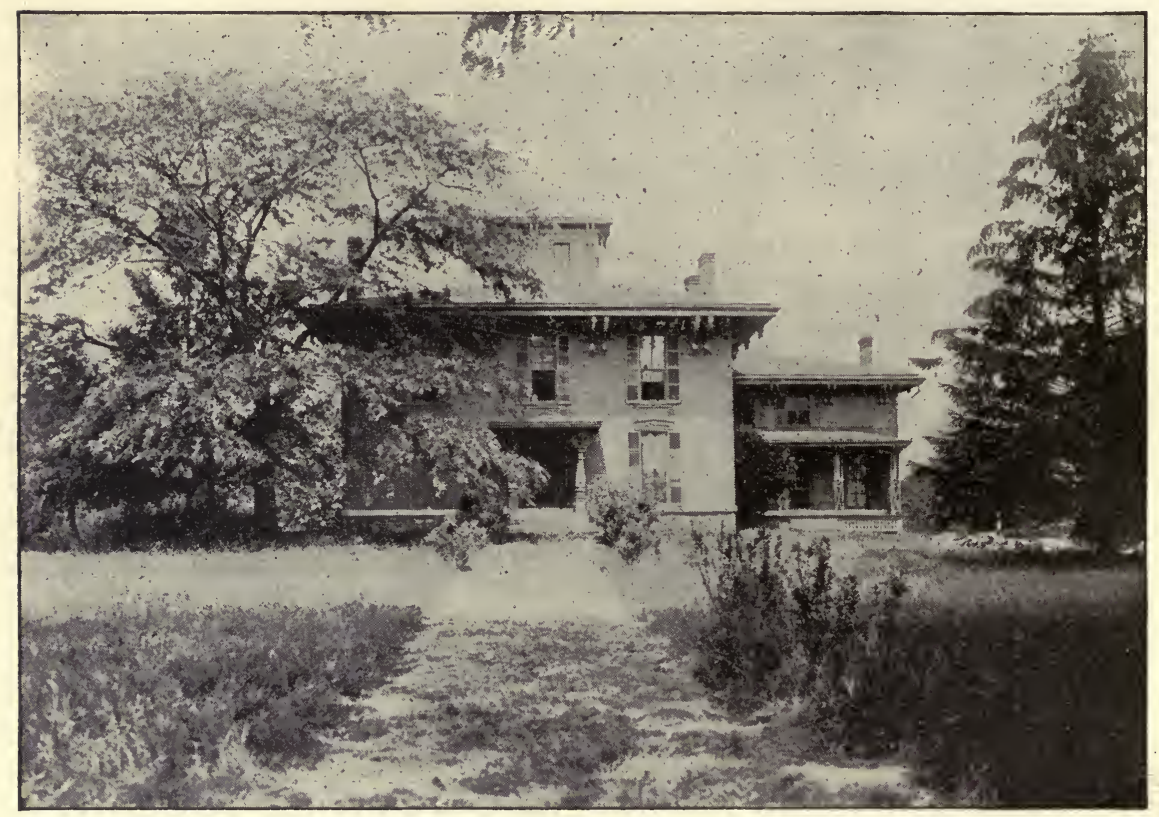

FIG. 28.-A Niagara County homestead. Residence of the late Dr. Ring

of the east to grow fruit of high quality, but so much of the grading and packing is faulty that the reputation of the entire product is thereby injured.

The native as well as the introduced enemies of the apple are no longer seriously feared by the first-class grower, but the acme of success will not be attained until Niagara growers, in common with the fruitproducers of other great apple-growing counties of western New York, reorganize and remodel in large measure present methods of finishing and handling their principal orchard product. That such a reorganization of method is now taking place and will go on rapidly in the future is conceded. 


\section{APPLE ORCHARD SURVEY OF NIAGARA COUNTY}

\section{GENERAL STATEMENT AND RESULTS*}

\section{By M. B. Cummings}

This bulletin is the product of field studies of apple orchards in Niagara County. It is a long story briefly told. The purpose, however, is to present the facts in regard to orchard management in Niagara County. It is a contribution of knowledge to the actual status of the apple industry of New York State. Contrasts and comparisons with conditions in Orleans (Bull. No. 229) and Wayne (Bull. No. 226) Counties can be made. The careful reader will find in the tables presented herewith, material for extensive studies. It would be interesting if each fruit grower would study these tables in relation to his own orchard.

Detailed descriptions of apple enemies and factors of orchard management are omitted. For a full discussion of these subjects the reader should consult Bulletin 226, entitled "An Apple Survey of Wayne County," which is an exhaustive treatise of general apple-orchard problems.

Methods of work.- The field studies were made in a manner very similar to that of previous surveys. The canvasser was provided with camera, note-book, bicycle, etc. The computations for yields and prices were based only on bearing orchards. In all cases, three bushels constitute a barrel. Only a few parts of the county were omitted. With the exception of Wheatfield, Pendleton, Royalton, and parts of Hartland, the entire county was surveyed. A few orchards as small as three acres were canvassed, although most of them of less than five acres were omitted. Thus, although many little orchards were left out large family orchards were included in this survey.

Size of the industry. - In I89o, according to the census report, Niagara County had I,033,454 apple trees of bearing age, which was the largest

* The orchard survey campaign. - This bulletin is the third in the series of orchard survey bulletins. The first two on the apple-growing of Wayne and Orleans Counties quickly ran out of print, attesting their usefulness in a very satisfactory way. The data for three additional surveys are in course of preparation. These cover Monroe, Orange and Ontario Counties. Other surveys will be undertaken as time and means permit. 
number of any county in the State. In I900, this number was reduced to 924,086 , which was still considerable above that of any other county in New York. A more recent census would undoubtedly show still greater reduction in the number of trees. With respect to yields for the year I889, Niagara ranked second, producing 623,204 bushels of apples, and was exceeded only by Wayne County. For the year I899, Niagara produced I,42I,796 bushels and still ranked second, being exceeded only by Monroe with an excess of 14,595 bushels.

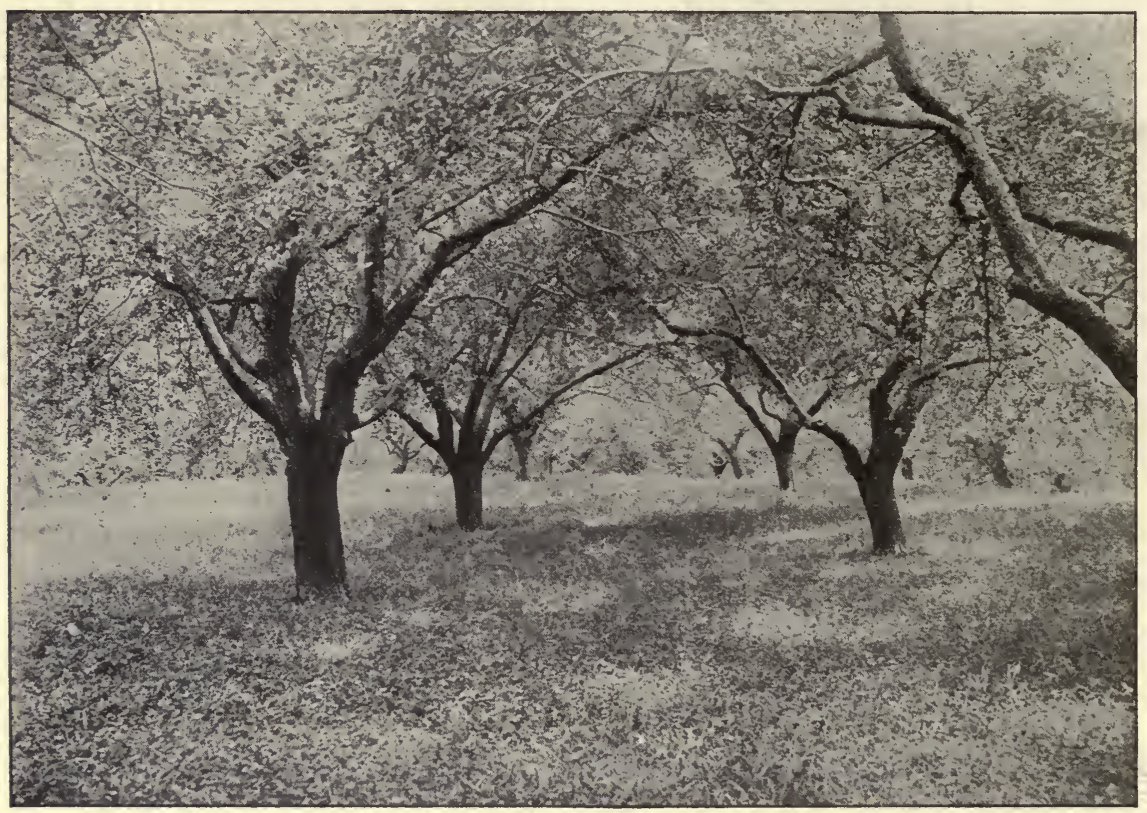

FIG. 29.-An old story: An example of an orchard in which the trees are crowding each other and are now "fighting it out"

Area in apples. - The entire area of the county comprises 522 square miles, or 334,080 acres, with an average of 46 acres in apples to the square mile. Furthermore, since there are 924,086 trees in the county, and since the average number of trees per acre is 38.2 it follows that there are about 24, I9O acres in apples. This means that 7.2 per cent of the area of the county is planted to apple orchards. About threefourths of the orchards are in the northern half of the county. More complete surveys were made in the lake-shore districts than elsewhere, although representative districts of the entire county were surveyed. 
Physiography.* - Niagara County measures about 18 by 29 miles, and embraces an area of 522 square miles. It includes parts of two rather distinct topographical regions. The northern part is the old lake bed, often called the Ontario plain, which extends from the lake to the base of the escarpment; and the ridge region, embracing the Niagara escarpment and a part of the Erie plain, extending as far south as North Tonawanda, and east through Lockport, and even farther.

The county is rather flat, aside from the ridge and its immediate vicinity. There is a slight, but rather general slope in the northern

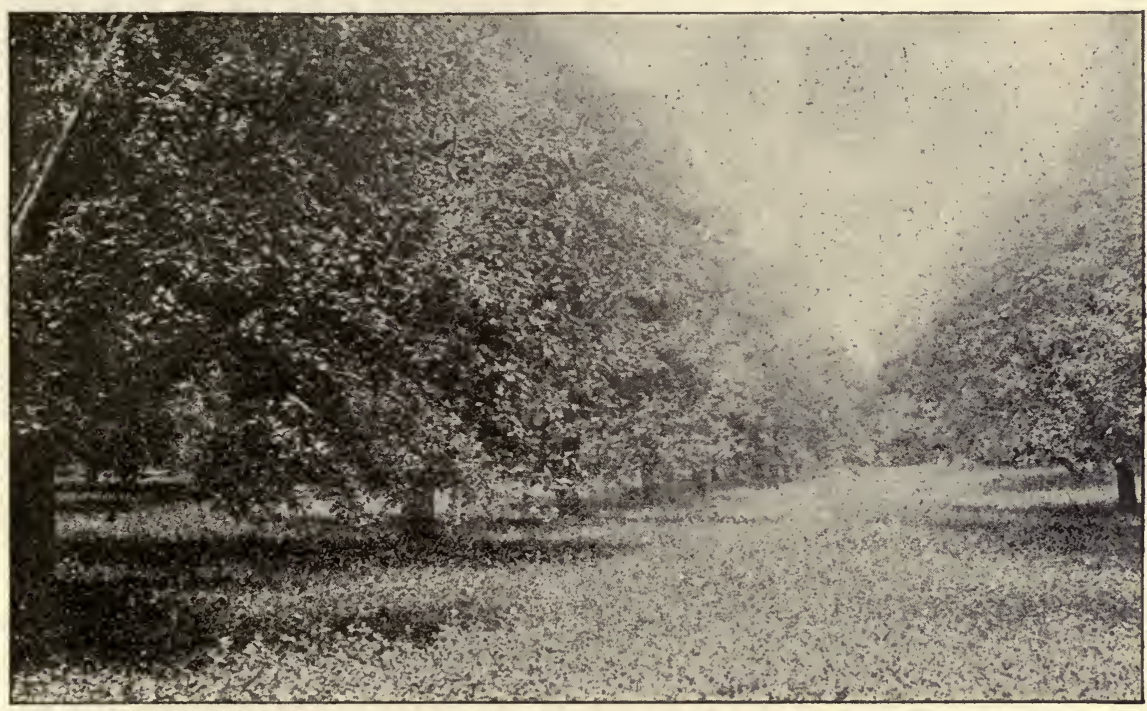

FIG. 30.-A Baldwin orchard on the Lake Road showing a good cover-crop of mammoth clover

part toward the lake, and in the southern part toward Buffalo and the south. There are only a few hills and a minimum of swamp area, but considerable mountain territory composed of a very durable stratum of Niagara limestone. There are no important rivers, ponds or valleys in the county. Much of the land on plains and on the plateau is too flat to allow of good natural drainage.

The Ontario plain is made up largely of Dunkirk soils, such as sand and clay loams. Such soils lend themselves easily to all methods of tillage, and here cultivation is the general practice. On the other hand, the mountain territory is, much of it, too rough and stony for thorough cultivation.

* For fuller description see report of field operations, Bureau of Soils, I 906. 
The climate is much influenced by Lake Ontario. Cool and moist winds from the lake are modifying and unifying factors. Local and seasonal precipitations are probably much affected by proximity to the lake. The temperature is doubtless higher in winter and lower in summer because of nearness to Ontario waters. Attention is drawn to this circumstance by the soil survey of the region, found in the Report of the Field Operations of the Bureau of Soils for 1906, page 75 .

Age of the orchards. - The accompanying table is interesting in showing the rise and decline of apple-orchard planting in the county. It is quite probable that a few orchards were planted previous to I820, but no records could be obtained to support this idea. Very few orchards were set before 1855 , and these were small ones for family rather than commercial purposes. Shortly after this date, however, large orchards were put out, and for a period of thirty-five years extensive plantings were made; in fact 75.9 per cent of the orchards now of bearing age were set between 1855 and 1879 .

The most significant feature of this table, however, is the one that shows the decline in plantings. This decline began about twenty-five years ago, and has rapidly continued till the time of this survey. This fact can hardly be attributed to the San José scale, for this insect has not been prevalent, or at least not troublesome for much more than six years. This matter of decreased plantings should not be looked upon too lightly by the fruit grower of this section, for the tendency is such as to cause alarm, and the final effect will be serious.

I. Different Periods of Planting

\begin{tabular}{|c|c|c|c|}
\hline DATE OF PLANTING. & $\begin{array}{l}\text { Number of } \\
\text { orchards. }\end{array}$ & $\begin{array}{l}\text { Number of } \\
\text { acres. }\end{array}$ & $\begin{array}{l}\text { Per cent } \\
\text { orchards. }\end{array}$ \\
\hline 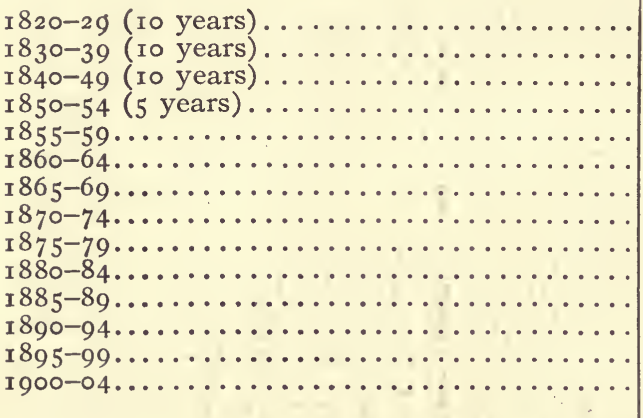 & $\begin{array}{r}\text { I } \\
8 \\
22 \\
30 \\
75 \\
\text { I00 } \\
47 \\
\text { I } 14 \\
\text { I05 } \\
36 \\
\text { I } 7 \\
\text { I } 2 \\
8 \\
6\end{array}$ & $\begin{array}{c}7 \\
49 \\
\mathrm{I} 95 \frac{1}{2} \\
279 \\
688 \\
920 \\
467 \\
\mathrm{I}, \mathrm{I} 36 \\
\mathrm{I}, 098 \\
385 \frac{1}{2} \\
\mathrm{I} 57 \\
\mathrm{I} 22 \\
38 \\
74\end{array}$ & $\begin{array}{r}.2 \\
\text { I.4 } \\
3.8 \\
5.2 \\
\text { I } 2.9 \\
\text { I } 7.2 \\
8.1 \\
\text { I } 9.6 \\
\text { I } 8.1 \\
6.2 \\
2.9 \\
2.1 \\
\text { I. } \\
\text { I. } \\
\end{array}$ \\
\hline
\end{tabular}


Age and yicld.- The period of maximum production seems to come between fifty and sixty-five years after planting. Some orchards or parts of orchards were seen, which were planted previous to 1830 , but no accurate data could be given of the yields so they were not used in this computation.

\section{Age and Yield per Acre in Bushels for All Parts of the County} SURVEYED

\begin{tabular}{|c|c|c|c|c|c|c|c|c|c|}
\hline \multirow{2}{*}{$\begin{array}{l}\text { DATE OF } \\
\text { PLANTING. }\end{array}$} & \multicolumn{3}{|c|}{1902 . } & \multicolumn{3}{|c|}{1903.} & \multicolumn{3}{|c|}{1904.} \\
\hline & $\begin{array}{l}\text { Num- } \\
\text { ber or- } \\
\text { chards. }\end{array}$ & $\begin{array}{l}\text { Num- } \\
\text { ber } \\
\text { acres. }\end{array}$ & $\begin{array}{l}\text { Aver- } \\
\text { age } \\
\text { yield. }\end{array}$ & $\begin{array}{l}\text { Num- } \\
\text { ber or } \\
\text { chards. }\end{array}$ & $\begin{array}{l}\text { Num- } \\
\text { ber } \\
\text { acres. }\end{array}$ & $\begin{array}{l}\text { Aver- } \\
\text { age } \\
\text { yield. }\end{array}$ & $\begin{array}{l}\text { Num- } \\
\text { ber or- } \\
\text { chards. }\end{array}$ & $\begin{array}{l}\text { Num- } \\
\text { ber } \\
\text { acres. }\end{array}$ & $\begin{array}{l}\text { Aver- } \\
\text { age } \\
\text { yield. }\end{array}$ \\
\hline $1830-39 \ldots \ldots \ldots$ & I & 9 & I I I & 3 & 49 & 89 & 2 & 14 & I I 7 \\
\hline $1840-49 \ldots \ldots$ & 4 & 40 & 98 & 5 & 39 & 88 & 4 & 40 & $2 \times 3$ \\
\hline $1850-54 \ldots \ldots$ & 2 & II & I 2 I & 6 & 78 & 107 & 5 & 76 & I73 \\
\hline $1855-59 \ldots \ldots \ldots \ldots$ & 9 & 94 & $26 I$ & 12 & I 57 & 106 & $x 6$ & I 73 & 106 \\
\hline $1860-64 \ldots \ldots \ldots \ldots \ldots$ & $3 \mathbf{I}$ & 297 & 96 & 37 & 408 & 109 & 45 & 456 & 102 \\
\hline $1865-69 \ldots \ldots \ldots \ldots \ldots$ & 33 & 356 & 97 & 48 & 458 & 127 & 69 & 730 & I62 \\
\hline I $870-74 \ldots \ldots \ldots \ldots \ldots$ & 30 & 267 & I 36 & 43 & $37 \mathrm{I}$ & 122 & 63 & 597 & 170 \\
\hline $1875-79 \ldots \ldots \ldots \ldots$ & 22 & 223 & 162 & 40 & 414 & 108 & $7 \mathrm{I}$ & 623 & 150 \\
\hline $1880-84 \ldots \ldots$ & I I & 105 & 198 & I 5 & 153 & 71 & 23 & I 23 & 129 \\
\hline $1885-89 \ldots$ & $\mathbf{r}$ & 4 & 150 & 3 & I 8 & II 5 & I & 4 & 160 \\
\hline
\end{tabular}

Age and Yield per Acre in Bushels for All Parts of the County Sưrveyed

\begin{tabular}{|c|c|c|c|c|c|c|c|c|}
\hline \multirow[b]{2}{*}{ DATE OF PLANTING. } & \multicolumn{3}{|c|}{1005.} & \multicolumn{3}{|c|}{ 1 906.} & \multicolumn{2}{|c|}{$\begin{array}{l}\text { Five-Year } \\
\text { AVERAGE. }\end{array}$} \\
\hline & $\begin{array}{l}\text { Num- } \\
\text { ber or- } \\
\text { chards. }\end{array}$ & $\begin{array}{l}\text { Num- } \\
\text { ber } \\
\text { acres. }\end{array}$ & $\begin{array}{l}\text { Aver- } \\
\text { age } \\
\text { yield. }\end{array}$ & $\begin{array}{l}\text { Num- } \\
\text { ber or } \\
\text { chards. }\end{array}$ & $\begin{array}{l}\text { Num- } \\
\text { ber } \\
\text { acres. }\end{array}$ & $\begin{array}{l}\text { Aver- } \\
\text { age } \\
\text { yield. }\end{array}$ & $\begin{array}{c}\text { Aver- } \\
\text { age age. }\end{array}$ & $\begin{array}{l}\text { Aver- } \\
\text { age } \\
\text { yield. }\end{array}$ \\
\hline r $830-39 \ldots \ldots \ldots \ldots \ldots$ & I & 5 & I 80 & 4 & 92 & 60 & $* 69$ & \\
\hline $1840-49 \ldots \ldots$ & 8 & 72 & 210 & 2 & $5 \mathrm{I}$ & 240 & $*_{59}$ & I70 \\
\hline$\cdots$ & 6 & 48 & 138 & 6 & 90 & 75 & 52 & I 23 \\
\hline .. & 20 & 210 & 158 & $3 \mathrm{I}$ & 216 & 208 & 47 & 168 \\
\hline $1860-64$ & 54 & 680 & 109 & 52 & 640 & 202 & 42 & I24 \\
\hline 1865 & 80 & $8 \mathrm{r}_{4}$ & 132 & 76 & 768 & 159 & 37 & 135 \\
\hline $\begin{array}{l}1870-74 . . \\
1875-70\end{array}$ & 72 & $\begin{array}{r}708 \\
878\end{array}$ & $\times 30$ & 99 & $33 \circ$ & 98 & 32 & $13 \mathrm{I}$ \\
\hline $\begin{array}{l}1875^{-} \\
1880^{-}\end{array}$ & 70 & 878 & 93 & 96 & 618 & 144 & 27 & $x 3 x$ \\
\hline $1880-84 \ldots \ldots$ & 36 & 384 & 164 & 22 & 300 & 123 & 22 & 137 \\
\hline$r 885-89 \ldots \ldots \ldots$ & 2 & I 7 & I98 & 3 & 15 & $7 \mathrm{I}$ & 17 & $\begin{array}{r}139 \\
39\end{array}$ \\
\hline $1890-94 \ldots \ldots \ldots$ & 5 & 45 & $9 \mathrm{r}$ & 4 & 36 & 72 & $x 2$ & (a) 82 \\
\hline
\end{tabular}

The comparatively high yield for the last two periods, namely, I88589 and $1890-94$, is due to the fact that these orchards were mostly of the Oldenburg (Dutchess) variety, which is an early bearer.

* Average age for a ten-year period. Each date of planting not known.

(a) Two year average. 


\section{SOILS}

The following data are abstracted from the eighth Report of the Bureau of Soils, the survey which formed the basis of the report on the Niagara sheet having been conducted in conjunction with the orchard survey in 1906.

There are seventeen soil types in Niagara County. Only five of these, however, have been used extensively for apple orchards, viz., Dunkirk loam, Dunkirk clay loam, Dunkirk silt loam, Clyde loam and Tonawanda clay.

\section{THE SOIL TYPES}

Dunkirk loam.- This occupies more territory than any other one soil, and has been used most largely for orchard plantations. Consider-

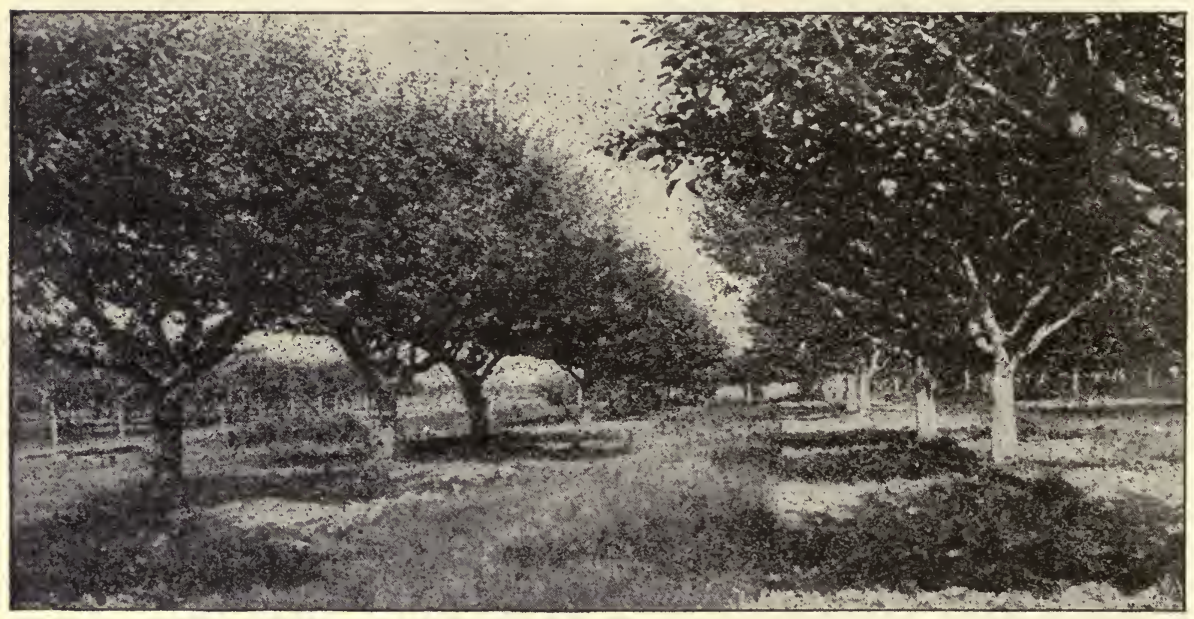

Fig. 3I.-Partial tillage with grass between the rows. Better than no cultivation, but not so good as thorough cultivation

able areas in Middleport, Gasport, North Wilson, Newfane, and Youngstown are of this sort. There is also a strip extending from Youngstown to Lewiston, and then eastward along the ridge from Lewiston to Lockport. This type of soil is derived from glacial material, and carries some sandstone and shale. It is a dark brown loam, eight to ten inches deep. The subsoil is a light brown, fine sandy loam, which is compact, and becomes darker in color and heavier in texture with depth. Stones are scattered through both subsoil and surface soil.

Dunkirk clay loam.- This ranks second in the area occupied. It is the most common type about Niagara Falls, Suspension Bridge, and toward Sanborn. This type is a stiff and heavy clay. It is dark 
brown to grayish brown, and runs to a depth of eight inches. It is generally free of gravel and stones. The compact character of this soil, and the fact that it is frequently found on depressed areas, renders drainage on it very poor.

Dunkirk silt loam.- This occurs along the lake from Youngstown eastward in interrupted areas. It is also common west of Gasport and Orangeport, and on toward Lockport. This type consists of a pale yellow to light brown silt loam. It is underlaid by a darker subsoil. It is sedimentary in origin, and represents the wash from higher shale slopes.

Clyde loam.-This occurs in the quadrangle delimited by Hickory Corners, Wilson, Youngstown, and Lewiston. The largest single area within this district is south and southwest of Wilson. This type is derived from glacial lake deposits. It is somewhat variable in color and appearance. It varies from a friable loam to a dark gray, brown or black color. The depth ranges from eight to twelve inches. It is much subject to puddling and when wet is sticky and impervious. On well-drained areas, however, it is mellow and pervious to water.

Tonawanda clay.- This is distributed uniformly from southern Niagara Falls to LaSalle, on toward North Tonawanda, and eastward toward Wheatfield. Tonawanda clay is much like Dunkirk clay loam. It is somewhat lighter in color, and is firmer in texture and consistency. It has a surface soil ranging in depth from five to twelve inches. It carries very. few stones, and but little gravel.

\section{Relation of Yields to Soll Types}

\begin{tabular}{|c|c|c|c|c|c|c|}
\hline \multirow{2}{*}{ KIND OF SOIL. } & \multicolumn{3}{|c|}{1902.} & \multicolumn{3}{|c|}{ I 903.} \\
\hline & $\begin{array}{l}\text { Number } \\
\text { of or- } \\
\text { chards. }\end{array}$ & $\begin{array}{c}\text { Number } \\
\text { of } \\
\text { acres. }\end{array}$ & $\begin{array}{l}\text { Aver- } \\
\text { age } \\
\text { yield. }\end{array}$ & $\begin{array}{l}\text { Number } \\
\text { of or- } \\
\text { chards. }\end{array}$ & $\begin{array}{c}\text { Number } \\
\text { of } \\
\text { acres. }\end{array}$ & $\begin{array}{l}\text { Aver- } \\
\text { age } \\
\text { yield. }\end{array}$ \\
\hline 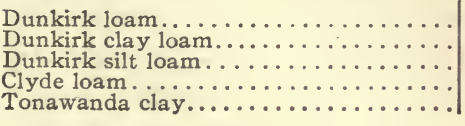 & $\begin{array}{r}68 \\
\text { I0 } \\
9 \\
7 \\
\text { II }\end{array}$ & $\begin{array}{r}770 \\
97 \\
107 \\
54 \\
91\end{array}$ & $\begin{array}{r}167 \\
148 \\
139 \\
57 \\
\text { I } 13\end{array}$ & $\begin{aligned} 71 \\
16 \\
\text { I } 1 \\
9 \\
16\end{aligned}$ & $\begin{array}{r}793 \\
113 \\
119 \\
67 \\
108\end{array}$ & $\begin{aligned} & \\
& 161 \\
& 157 \\
& 141 \\
& 73 \\
& 121\end{aligned}$ \\
\hline 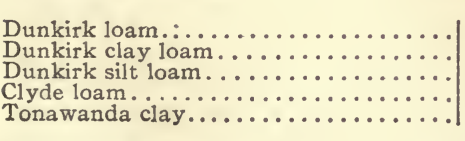 & $\begin{array}{l}74 \\
28 \\
25 \\
13 \\
29\end{array}$ & $\begin{array}{r}1904 \\
789 \\
279 \\
341 \\
179 \\
260\end{array}$ & $\begin{array}{r}174 \\
157 \\
145 \\
84 \\
120\end{array}$ & $\begin{array}{l}83 \\
33 \\
27 \\
18 \\
33\end{array}$ & $\begin{array}{r}1905 \\
826 \\
301 \\
360 \\
197 \\
273\end{array}$ & $\begin{aligned} 160 \\
151 \\
141 \\
73 \\
\times 13\end{aligned}$ \\
\hline 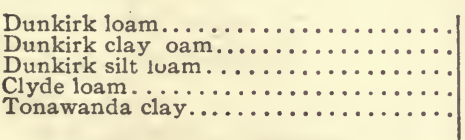 & $\begin{array}{l}\cdots \cdots \\
\ldots \cdots \\
\cdots \cdots \\
\cdots \cdots \\
\cdots \cdots\end{array}$ & $\begin{array}{l}\cdots \cdots \\
\cdots \cdots \\
\cdots \cdots \\
\cdots \cdots\end{array}$ & $\begin{array}{l}\cdots \cdots \\
\ldots \ldots \\
\ldots \cdots \\
\ldots \cdots \\
\cdots \cdots\end{array}$ & $\begin{array}{l}81 \\
30 \\
27 \\
21 \\
33\end{array}$ & $\begin{array}{l}1906 . \\
833 \\
291 \\
360 \\
174 \\
273\end{array}$ & $\begin{array}{r}\times 59 \\
135 \\
\times 35 \\
60 \\
105\end{array}$ \\
\hline
\end{tabular}


Yields on different soil types.-Table III shows that the Dunkirk soils give larger yields than the other types. It shows also that Clyde loam is considerably inferior to all others. It is probable that the Clyde loam yields are too low, but a smaller number of orchards and acres were used in this computation, so the averages are not so well substantiated. After all, the orchards on the Clyde loam were not neglected ones, so the figures are correct as far as they go.

Selection of orchards. - In order to increase the value of this study of yields on different soil types, the orchards were selected with considerable

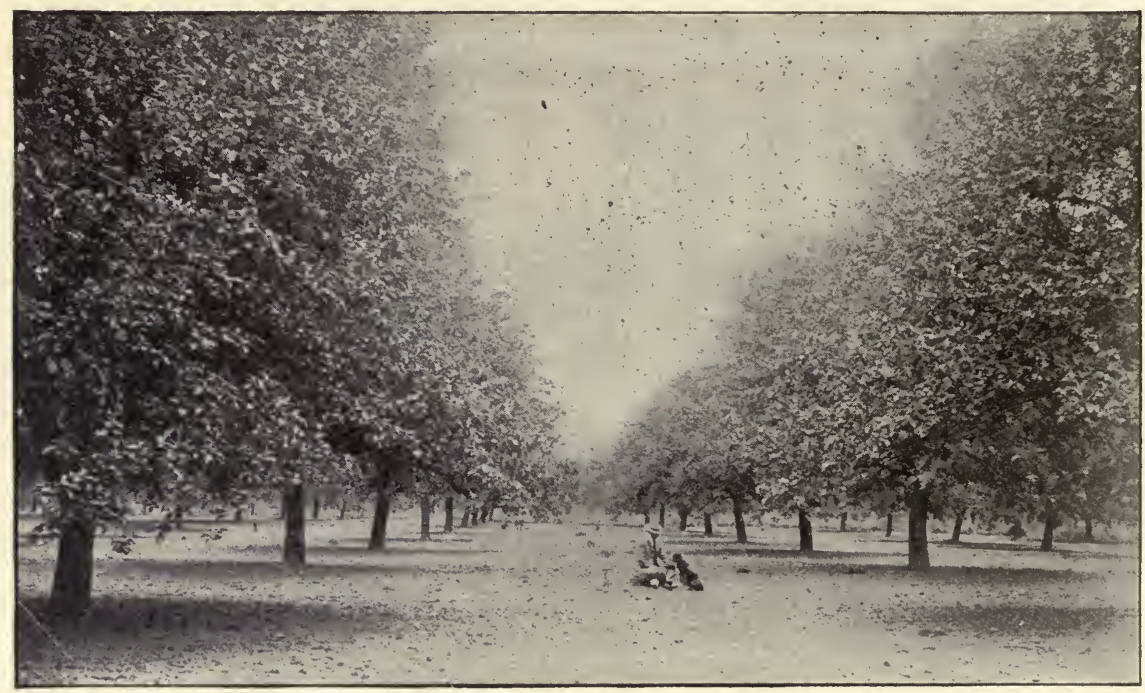

FIG. 32.-After " thinning," by cutting out every other row diagonally through the orchard

care. All scale-infested orchards were excluded and only those orchards were considered which had received, so far as could be told, nearly equal and uniform care. No neglected orchards were included. This sifting process reduces the acreage considerably, but seems to be the only fair method of procedure.

\section{DRAINAGE}

A study of the accompanying table on drainage shows that a little more than half ( 52.2 per cent) of the orchards have good drainage; about one-fourth (26.3 per cent) have fair drainage; IO.5 per cent have poor, and II.I per cent have locally bad drainage. Furthermore, it may be seen that there are more orchards and more acres with locally bad 
drainage than with poor drainage. Now if it pays to have good drainage on the whole area of an orchard, it should pay equally well to drain any part that needs it. It is frequently these locally bad areas that determine the profit, for such sections receive as much care in tilling, spraying, and pruning but they give little or no return in crops.

Another feature shown by the table is the small proportion of orchards which are given artificial drainage; and still another is the number of acres of trees killed or damaged through failure to provide good drainage. It becomes clear, that little attention is given to soil drainage.*

IV. DRAINAGE

\begin{tabular}{|c|c|c|c|}
\hline DRAINAGE. & $\begin{array}{l}\text { Number of } \\
\text { orchards. }\end{array}$ & $\begin{array}{c}\text { Number of } \\
\text { acres. }\end{array}$ & $\begin{array}{l}\text { Per cent } \\
\text { orchards. }\end{array}$ \\
\hline \multicolumn{4}{|l|}{ Character of drainage: } \\
\hline 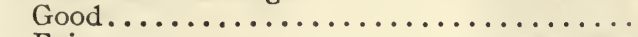 & 302 & 2,839 & $5^{2} .2$ \\
\hline 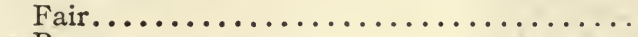 & 152 & $I, 63 I$ & 26.3 \\
\hline Poor.............. & $6 r$ & 536 & 10.5 \\
\hline Locally bad.............. & 64 & 625 & I I. I \\
\hline \multicolumn{4}{|l|}{ Nature of drainage: } \\
\hline Natural......... & 579 & $5,43 \mathrm{I}$ & 93.8 \\
\hline Tile drained...... & 20 & 305 & 3.2 \\
\hline Stone drained........... & 2 & 22 & $\cdot 3$ \\
\hline Surface ditched.......... & I6 & 190 & 2.6 \\
\hline \multicolumn{4}{|l|}{ Effect on the trees: } \\
\hline Trees killed.............. & I3 & 107 & $一$ \\
\hline Trees badly damaged.............. & 4 & 75 & - \\
\hline
\end{tabular}

\section{FERTILIZATION}

In recent years, the orchards in the county have been very sparingly fertilized. No figures were gathered regarding the use of fertilizers previous to 1900 , but since that date about eighty in every one hundred orchards have been enriched in some way. But this estimate, though accurate, is almost misleading, for any orchard that has received any fertilizer whatsoever, and even in very small quantities and at very infrequent intervals, has been classed as an enriched orchard. Many farmers do not apply manure oftener than once in six years, and rather a large number plan to cover orchard land once in ten years. Yet variable as the custom is, it has been found that of 622 orchards surveyed 484 , or 77.8 per cent, have received some fertilizing material, and 138 , or 22.2 per cent, have never received any.

Barnyard manure has been used most largely; this is followed by green-manuring with cover-crops, while commercial fertilizers rank third

*An instructive discussion of drainage is found in Bul. 254 , Cornell University Exp. Station: 
in general use. The need and value of fertilizers for orchards have been demonstrated beyond question in Wayne County, as well as in other sections of the country, and more attention might well be given

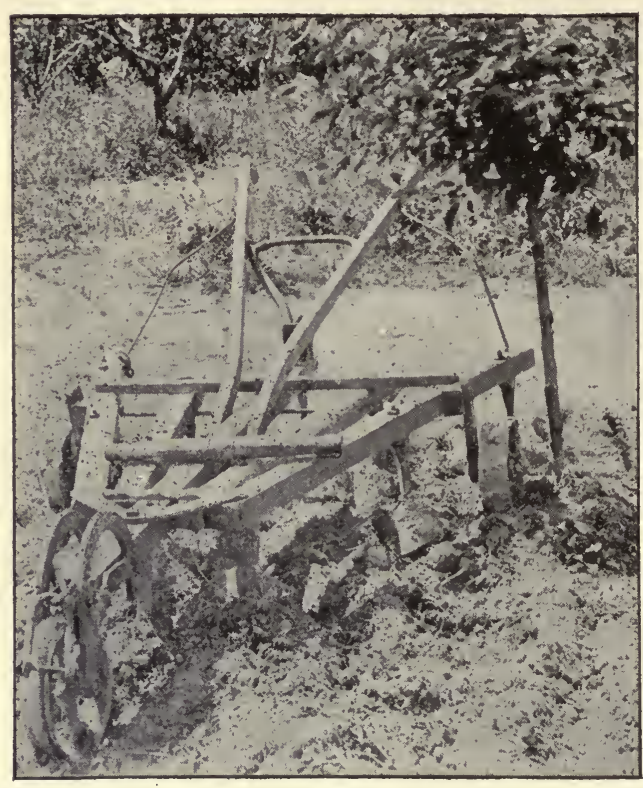

Fig. 33.-A poor type of cultivator for orchard use. Both frame and handles "skin" many trees to this factor of orchard management.

Commercial fertilizers have not come into very general use in the county; in fact, about 4.3 per cent of the area (acres) is enriched by commercial fertilizers alone and in combination with other fertilizers. A few orchardists use commercial fertilizer in connection with manures, some use ashes with manures, and 4 per cent (of orchards) use commercial fertilizers alone. Complete fertilizers are used in only thirteen orchards and on I I 9 acres. Frequently the phosphorus is entirely omitted.

Cover-crops have also been rather unpopular. They have been used on only about ten per cent of the orchards. Buckwheat, rye and clovers are the chief kinds used. Green-manuring by the use of cover-crops might well come into more general use, and in this way serve as a substitute for barnyard manure and other fertilizers.

V. Summary of Fertilizers Used on Bearing Orchards

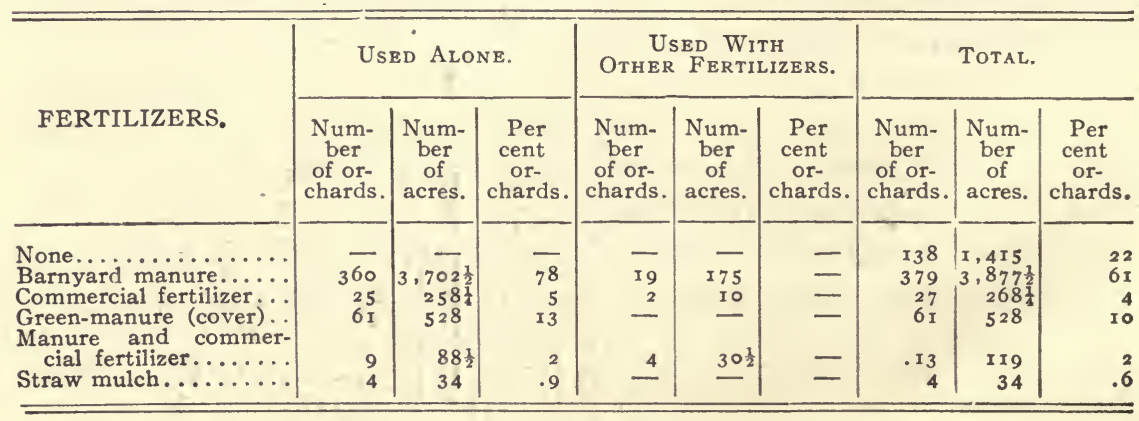


VI. Kinds of Commercial Fertilizers

\begin{tabular}{|c|c|c|}
\hline FERTILIZERS. & $\begin{array}{l}\text { Number of } \\
\text { orchards. }\end{array}$ & $\begin{array}{l}\text { Number of } \\
\text { acres. }\end{array}$ \\
\hline 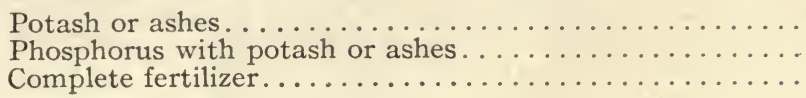 & $\begin{array}{r}8 \\
9 \\
3\end{array}$ & $\begin{array}{r}73 \\
106 \\
20 \frac{1}{2}\end{array}$ \\
\hline
\end{tabular}

Three-Year Average Income per Acre for all Fertilizers

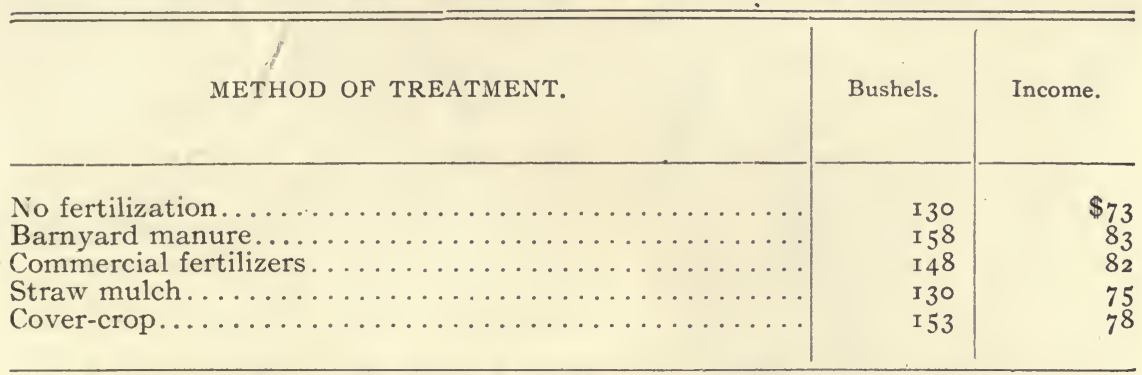

The following results were found for Wayne County (Bull. No. 226) :

Yield in Bushels for I 902 and I903 for Fertilized and Unfertilized Orchards. Trees Set Before i 880

\begin{tabular}{|c|c|c|c|c|c|c|c|}
\hline \multirow{2}{*}{ TREATMENT. } & \multicolumn{3}{|c|}{1902.} & \multicolumn{3}{|c|}{ I 903.} & \multirow{2}{*}{$\begin{array}{l}\text { Two- } \\
\text { year } \\
\text { average } \\
\text { yield. }\end{array}$} \\
\hline & $\begin{array}{l}\text { Number } \\
\text { orchards. }\end{array}$ & Acres. & $\begin{array}{l}\text { Average } \\
\text { yield. }\end{array}$ & $\begin{array}{l}\text { Number } \\
\text { orchards. }\end{array}$ & Acres. & $\begin{array}{l}\text { Average } \\
\text { yield. }\end{array}$ & \\
\hline $\begin{array}{l}\text { Fertilized } \ldots \ldots \ldots \ldots \ldots \ldots \ldots \\
\text { Unfertilized } \ldots \ldots \ldots \ldots \ldots \ldots\end{array}$ & $\begin{array}{l}292 \\
\text { III }\end{array}$ & $2, \underset{692}{1} 61$ & $\begin{array}{l}233 \\
\text { I } 73\end{array}$ & $\begin{array}{r}147 \\
44\end{array}$ & $\begin{aligned} I, & 210 \frac{1}{2} \\
& 343 \frac{1}{2}\end{aligned}$ & $\begin{array}{l}28 \mathrm{I} \\
23 \mathrm{I}\end{array}$ & $\begin{array}{l}257 \\
202\end{array}$ \\
\hline
\end{tabular}

\section{TILLAGE}

Acreage of tilled and untilled orchards. - Precisely one-third of the orchards had been tilled for a ten-year period previous to 1906; and fifteen per cent have been in sod for this period. Seventeen per cent, or a little less than one-fifth, had been tilled for five years, and about an equal number had been in sod for this period. 
ViI. Treatment Prior to igo6. Mature Orchards

\begin{tabular}{|c|c|c|c|}
\hline TREATMENT. & $\begin{array}{l}\text { Number of } \\
\text { orchards. }\end{array}$ & $\begin{array}{l}\text { Number of } \\
\text { acres. }\end{array}$ & $\begin{array}{l}\text { Per cent } \\
\text { orchards. }\end{array}$ \\
\hline Tilled ten years or more... & 142 & I, 343 & $33 \cdot 9$ \\
\hline Tilled five years or more $\ldots \ldots \ldots \ldots \ldots \ldots \ldots$ & $7 \mathrm{I}$ & 233 & 16.9 \\
\hline Tilled over half of preceding five years....... & 32 & 423 & 7.6 \\
\hline Sod over half of preceding five years.......... & 53 & 643 & I 2.7 \\
\hline 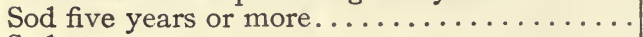 & 57 & 613 & 13.6 \\
\hline 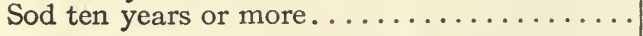 & 64 & 627 & I $5 \cdot 3$ \\
\hline
\end{tabular}

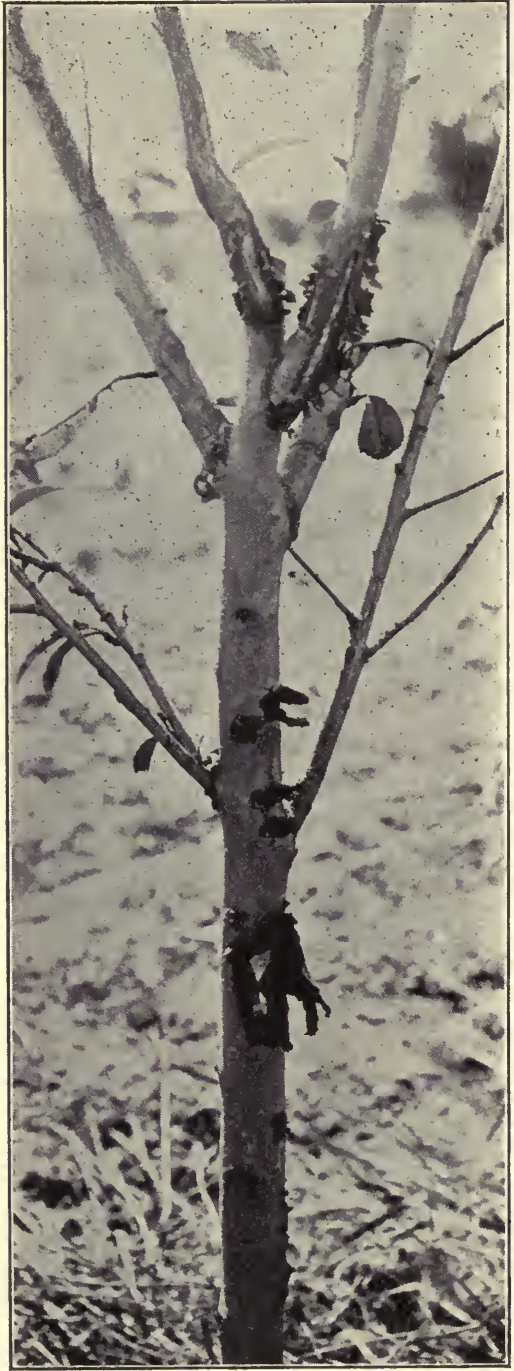

FIG. 34.-The work of the "skinning" type of cultivator
Methods of sod treatment.-Sod orchards not pastured have given much better results on the average than sod orchards handled in any other way, but in Niagara County there are special reasons for this. In the first place, the unpastured sod orchards receive better care. A sod orchard that is not pastured does not mean a neglected orchard. A good many growers who have orchard land handled in this manner make it a point to prune well, spray well, and fertilize well; and although they do not cultivate or pasture, yet they may get good crops. The much larger number of orchards and acres in sod and not pastured is an indication that some of the fruit producers have found out these things for themselves. Again, the unpastured sod orchards are generally younger than pastured ones.

On the other hand, sod orchards which are pastured with cattle, sheep, or even with hogs, are more likely to be neglected. There are two reasons for this. One is the presence of scale, and the other is the tendency to pasture the orchards which have passed beyond the period of largest crops.

With respect to the method of pasturing, hogs have given better re- 
sults than any of the other animals. Sheep rank second, while cows or horses give the poorest results of any. These latter results correspond with those obtained in Orleans and Wayne counties, and tend to support the rapidly-developing principle that if one must pasture he should use hogs rather than any other animals.

ViII. Yield in Bushels with Various Methods of Sod Treatment

\begin{tabular}{|c|c|c|c|c|c|c|c|c|c|}
\hline \multirow{2}{*}{$\begin{array}{l}\text { METHOD } \\
\text { OF TREATMENT }\end{array}$} & \multicolumn{3}{|c|}{ I904. } & \multicolumn{3}{|c|}{1905.} & \multicolumn{3}{|c|}{ I 906.} \\
\hline & $\begin{array}{l}\text { Num- } \\
\text { ber or- } \\
\text { chards. }\end{array}$ & $\begin{array}{l}\text { Num- } \\
\text { ber } \\
\text { acres. }\end{array}$ & $\begin{array}{l}\text { Aver- } \\
\text { age } \\
\text { yield. }\end{array}$ & $\begin{array}{l}\text { Num- } \\
\text { ber or- } \\
\text { chards. }\end{array}$ & $\begin{array}{l}\text { Num- } \\
\text { ber } \\
\text { acres. }\end{array}$ & $\begin{array}{l}\text { Aver- } \\
\text { age } \\
\text { yield. }\end{array}$ & $\begin{array}{l}\text { Num- } \\
\text { ber or- } \\
\text { chards. }\end{array}$ & $\begin{array}{l}\text { Num- } \\
\text { ber } \\
\text { acres. }\end{array}$ & $\begin{array}{c}\text { Aver- } \\
\text { age } \\
\text { yield. }\end{array}$ \\
\hline $\begin{array}{l}\text { Pastured with hogs..... } \\
\text { Pastured with sheep.... } \\
\text { Pastured with cattle.... } \\
\text { Not pastured. . . . . . } \\
\text { Pastured and plowed on } \\
\text { alternate years.... }\end{array}$ & $\begin{array}{r}20 \\
24 \\
26 \\
135 \\
2\end{array}$ & $\begin{array}{r}166 \\
298 \\
385 \\
\Gamma, 382 \\
18\end{array}$ & $\begin{array}{r}\text { I } 44 \\
\text { I } 37 \\
87 \\
\text { I } 79 \\
90\end{array}$ & $\begin{array}{r}23 \\
24 \\
34 \\
185\end{array}$ & $\begin{array}{r}203 \\
321 \\
428 \\
1,745 \\
25\end{array}$ & $\begin{array}{r}130 \\
113 \\
74 \\
123 \\
120\end{array}$ & $\begin{array}{r}26 \\
20 \\
33 \\
189 \\
1\end{array}$ & $\begin{array}{r}210 \\
250 \\
390 \\
1,817 \\
5\end{array}$ & $\begin{array}{r}141 \\
139 \\
90 \\
125\end{array}$ \\
\hline
\end{tabular}

Three-Year Average per Acre:

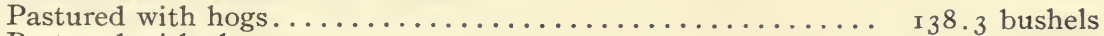

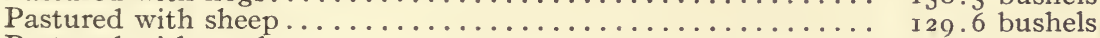

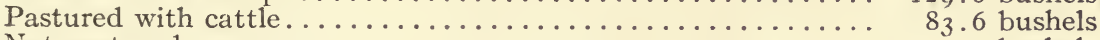

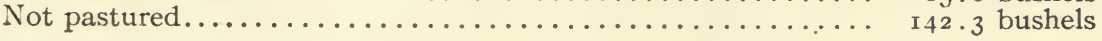

A computation for Orleans County gave the following results:

Three-Year Average Per Acre:*

Pastured with hogs ........................... 312 bushels

Pastured with sheep................................... 308 bushels

Pastured with cattle.......................... ${ }_{153}$ bushels

Not pastured................................... ${ }_{2} \mathrm{I}_{7}$ bushels

Treatment in 1905 of mature orchards.- In 1905 the mature orchards were variously treated. A classification of treatment places the methods under ten different headings (see Table IX). By far the largest number of orchards, about 44 per cent, were tilled without cover-crops. The next largest number or group, including $\mathrm{I} 3 \mathrm{I}$ orchards of $\mathrm{I}, \mathrm{I} 67$ acres, which is 24.5 per cent, was in sod with the grass cut and left under the trees. A few orchards were given cover-crops, and a small number were used for hoed crops.

The last group, receiving miscellaneous treatment, is made up of those in which cultivation was given only to parts of the orchard, or in which some pasturing and plowing, but without regular tillage, was the practice.

* The three years are not the same in both cases, which undoubtedly accounts in large measure for the difference in yields. 
IX. Treatment in igo5 of Mature Orchards

\begin{tabular}{|c|c|c|c|}
\hline TREATMENT. & $\begin{array}{l}\text { Number } \\
\text { orchards. }\end{array}$ & $\begin{array}{l}\text { Number. } \\
\text { acres. }\end{array}$ & $\begin{array}{l}\text { Per cent } \\
\text { orchards. }\end{array}$ \\
\hline 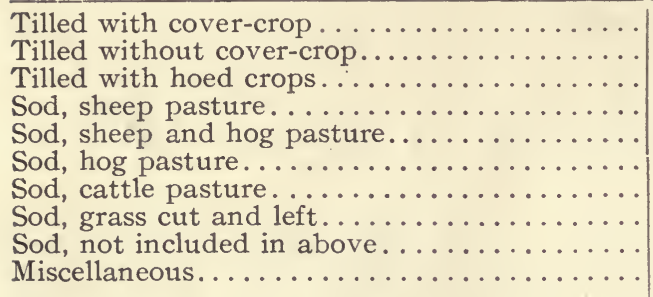 & $\begin{array}{r}34 \\
235 \\
9 \\
26 \\
4 \\
32 \\
3 \mathrm{I} \\
\mathrm{I} \\
3 \mathrm{I} \\
32 \\
28\end{array}$ & $\begin{array}{r}339 \frac{1}{2} \\
2,189 \\
\text { I } 16 \\
279 \\
39 \\
308 \\
339 \frac{1}{2} \\
\text { r } 167 \\
268 \\
449 \frac{1}{2}\end{array}$ & $\begin{array}{r}6.4 \\
44 \\
1.7 \\
4 \cdot 9 \\
.8 \\
6.0 \\
5.8 \\
24.5 \\
6.0 \\
(a)\end{array}$ \\
\hline $\begin{array}{l}\text { Total tilled. } \ldots \ldots \ldots \ldots \ldots \ldots \ldots \ldots \ldots \ldots \ldots \ldots \ldots \ldots \ldots \ldots \\
\text { Total Sod } \ldots \ldots \ldots \ldots \ldots \ldots \ldots \ldots\end{array}$ & $\begin{array}{l}278 \\
256\end{array}$ & $\begin{array}{l}2,644 \frac{1}{2} \\
2.400 \frac{1}{2}\end{array}$ & $\begin{array}{r}49 \\
47 \cdot 7\end{array}$ \\
\hline
\end{tabular}

(a) Not included in percentage determinations.

X. Treatment in 1905 of Young Trees. (Set Since i 895)

\begin{tabular}{|c|c|c|c|}
\hline TREATMENT. & $\begin{array}{l}\text { Number } \\
\text { orchards. }\end{array}$ & $\begin{array}{l}\text { Number } \\
\text { acres. }\end{array}$ & $\begin{array}{l}\text { Per cent } \\
\text { orchards. }\end{array}$ \\
\hline $\begin{array}{l}\text { Tilled, planted to a cultivated crop } . \ldots \ldots \ldots \\
\text { Tilled, sowed to grain crop. } \ldots \ldots \ldots \ldots\end{array}$ & $\begin{array}{l}8 \\
2\end{array}$ & $\begin{array}{l}98 \\
\text { II }\end{array}$ & $\begin{array}{l}72 \cdot 7 \\
18.2\end{array}$ \\
\hline Sod, hay cut. $\ldots \ldots \ldots \ldots \ldots \ldots \ldots \ldots$ & I & 6 & 9. I \\
\hline
\end{tabular}

Soil methods with young orchards in 1905.- Most of the young orchards in 1905 were given proper soil treatment; 72.7 per cent were planted with hoed or cultivated crops, I8.2 per cent were sown to grain and only 9.I per cent were left in sod and handled as a hay field.

Average returns in relation to soil treatment.- A careful study of yields and prices was made to determine what relation exists between soil treatment and profits. The product of these computations in terms of averages is given in the accompanying table. These tabulations cover a period of ten years or more, and extend over the entire county, and therefore furnish a fairly accurate index to the economic status of this factor of orchard management. If the reader consults a table of these averages for any individual year, he may find some inexplicable figures; but these should be viewed as arising out of peculiar environmental conditions. However, we are concerned more with the general rule, and thus find the most reliable information comes from a study of the five-year averages.

The table of five-year averages shows that a long-term tillage, say ten or more years, gives not only the largest yield, but also the largest income. A long-term tillage is far superior to a long term of sod treatment. This table shows also that a five- or even three-year tillage 
is much better than the same period with sod treatment. The conclusion of the whole matter is this: certain sod orchards under special conditions, such as heavy manure mulching, together with some pasturing to keep the grass down, give good results,- perhaps as good as clean cultivation. But the skillful fruit grower can expect more than the law of averages will give. And even the general grower should note that thorough tillage is the most profitable method of soil management.

XI. Average Yield in Bushels and Average Income per Acre of Sod and Tilled Orchards

\begin{tabular}{|c|c|c|c|c|}
\hline \multirow[b]{2}{*}{ METHOD OF TREATMENT. } & \multicolumn{4}{|c|}{. $\quad$ 1902. } \\
\hline & $\begin{array}{l}\text { Number } \\
\text { orchards. }\end{array}$ & $\begin{array}{l}\text { Number } \\
\text { acres. }\end{array}$ & $\begin{array}{l}\text { A verage } \\
\text { yield. }\end{array}$ & $\begin{array}{l}\text { Average } \\
\text { income. }\end{array}$ \\
\hline 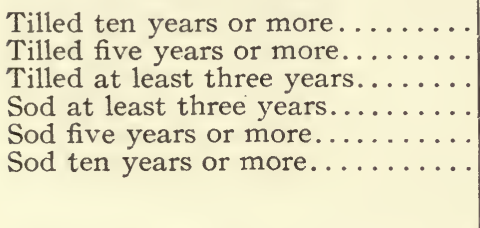 & $\begin{array}{r}57 \\
22 \\
10 \\
8 \\
4 \\
14\end{array}$ & $\begin{array}{r}645 \\
185 \\
88 \\
93 \\
44 \\
144 \\
\quad 19\end{array}$ & $\begin{array}{l}\text { I } 86 \\
\text { I } 39 \\
\text { I } 65 \\
\text { I } 57 \\
\text { I } 45 \\
\text { I } 81\end{array}$ & $\begin{array}{r}\text { \$r } 34 \\
88 \\
\text { ro4 } \\
58 \\
83 \\
\text { 105 }\end{array}$ \\
\hline 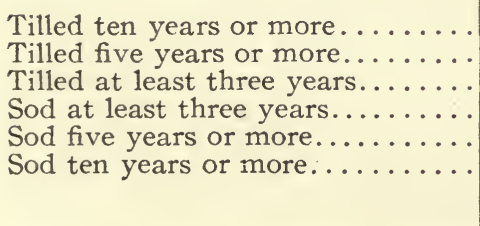 & $\begin{array}{r}100 \\
40 \\
27 \\
18 \\
18 \\
31\end{array}$ & $\begin{array}{r}\text { I, 040 } \\
405 \\
368 \\
353 \\
292 \\
28 I \\
\end{array}$ & $\begin{array}{l}408 \\
326 \\
214 \\
278 \\
280 \\
264\end{array}$ & $\begin{array}{r}\text { \$ } 48 \\
\text { I I } 7 \\
\text { I } 41 \\
82 \\
\text { I } 27 \\
\text { I03 }\end{array}$ \\
\hline 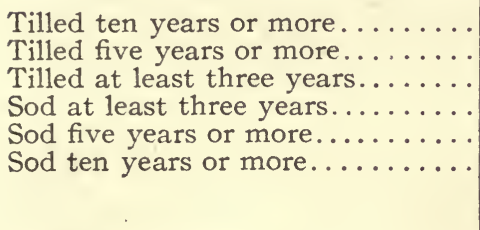 & $\begin{array}{r}\text { I } 17 \\
55 \\
44 \\
53 \\
20 \\
38\end{array}$ & $\begin{array}{r}\text { I, } 203 \\
573 \\
239 \\
767 \\
566 \\
338 \\
\text { I9 }\end{array}$ & $\begin{array}{l}282 \\
224 \\
230 \\
\text { I } 74 \\
171 \\
\text { I } 60\end{array}$ & $\begin{array}{r}\text { \$ } 26 \\
\text { I } 25 \\
\text { I3I } \\
87 \\
83 \\
84\end{array}$ \\
\hline 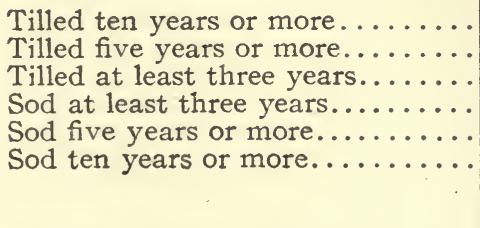 & $\begin{array}{l}28 \\
20 \\
18 \\
48 \\
35 \\
13\end{array}$ & $\begin{array}{r}406 \\
179 \\
182 \\
577 \\
450 \\
146 \\
19\end{array}$ & $\begin{array}{l}258 \\
312 \\
300 \\
271 \\
218 \\
192\end{array}$ & $\begin{array}{r}\$ 71 \\
91 \\
49 \\
53 \\
37 \\
35\end{array}$ \\
\hline 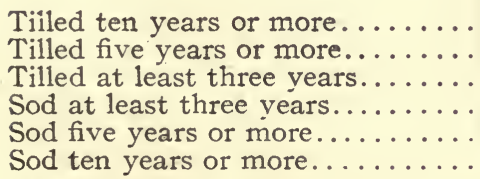 & $\begin{array}{l}34 \\
22 \\
16 \\
38 \\
37 \\
29\end{array}$ & $\begin{array}{l}342 \\
309 \\
240 \\
434 \\
338 \\
332\end{array}$ & $\begin{array}{l}261 \\
270 \\
285 \\
165 \\
170 \\
165\end{array}$ & $\begin{array}{r}\$ 12 \text { I } \\
80 \\
60 \\
57 \\
5 \text { I } \\
48\end{array}$ \\
\hline
\end{tabular}


Five-year Average per Acre

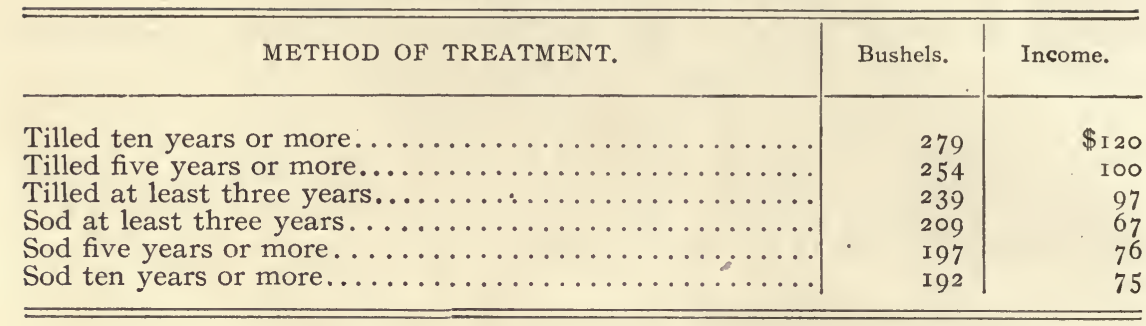

The results for Orleans County (Bull. No. 229) furnish an interesting comparison (four of the calendar years are the same in the two cases):

Average Yield in Bushels and Income per Acre of Tilled and Sod Orchards. $\Lambda$ Ll Orchards

Five-year Average per Acre

\begin{tabular}{|c|c|c|}
\hline METHOD OF TREATMENT. & Bushels. & Income. \\
\hline 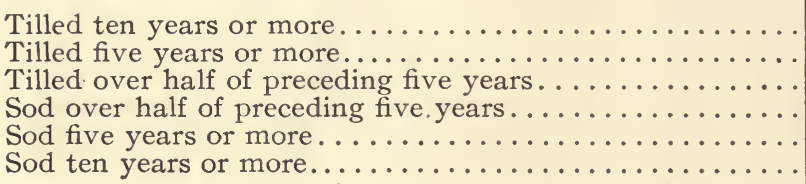 & $\begin{array}{l}327 \\
274 \\
225 \\
222 \\
204 \\
176\end{array}$ & $\begin{array}{r}\$ 182 \\
\text { I } 38 \\
\text { I } 13 \\
\text { I07 } \\
\text { I08 } \\
87\end{array}$ \\
\hline
\end{tabular}

Average Yield in Bushels and Income per Acre of Tilled and Sod Orchards. Orchards All Well Cared For

Five-year Average per Acre

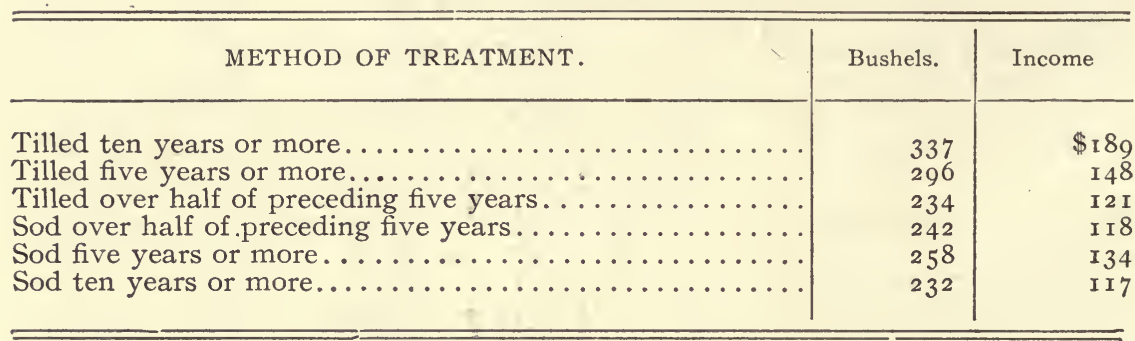

\section{ENEMIES OF THE APPLE}

The codling moth and the San José scale have been and are still the worst enemies of the apple in Niagara County. The codling moth is an ever-present pest in every orchard of much size in the county, 
but its ravages have been much reduced and fairly well controlled where careful sprayings have been given.

The San José scale, although not so widely spread as the codling moth or some other insects, has been far more destructive than all other pests combined. In fact, the loss of fruit and the destruction of trees have been so great as to threaten the eradication of the whole apple industry in the western part of the county. This alarming outlook is due more to a combination of unfavorable conditions than to the character of the scale or the inefficiency of spray mixtures. For the

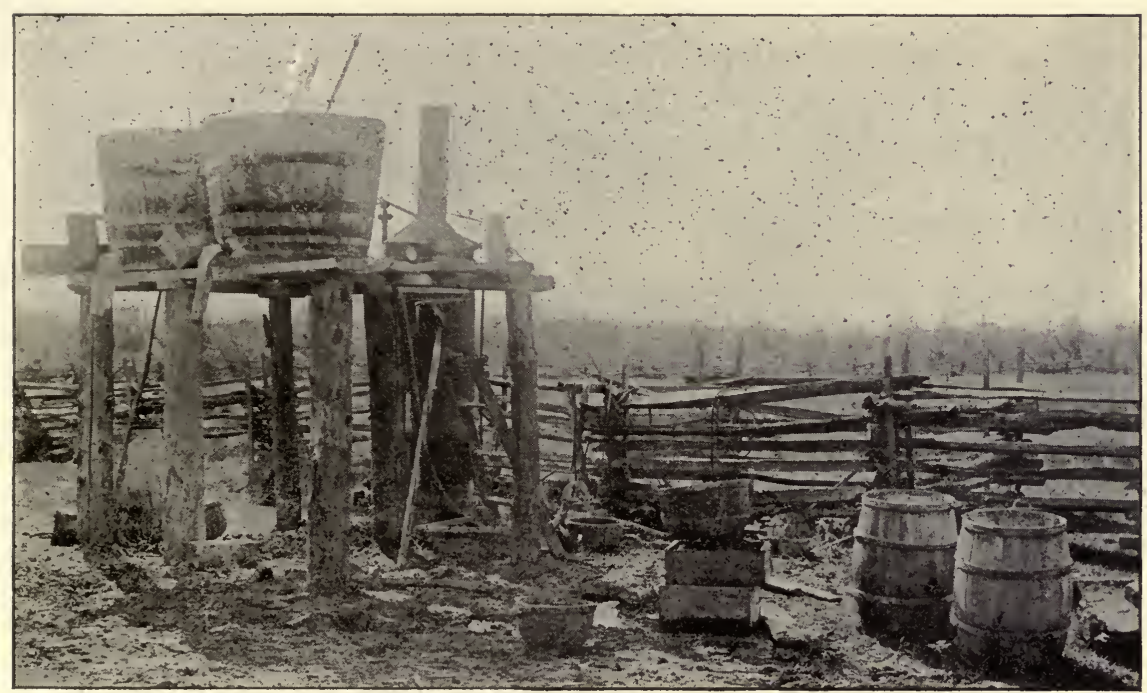

FIG. 35.-A good equipment for making lime and sulfur. The engine pumps water from a pool at left, and the boiler furnishes steam for cooking the mixture

past three years, the special difficulties have been of three kinds, and these are associated with climate, the management of the trees, and the attitude of the fruit growers. Each of these may be briefly treated.

Many growers have been bothered to find suitable weather for spraying. In spring, when most of the spraying for scale has been done, there were frequent rains, strong winds, or wind in the wrong direction; or in some instances, a combination of all three. In consequence of these obstacles a few orchards were not sprayed at all, while some others were only partially sprayed, and in still other cases an ineffective spraying was all that could be accomplished.

In the second category of difficulties comes an improper management of the trees. By this is meant a failure to keep the trees within 
manageable limits. A great many of the orchards contain trees that are too large and high to make spraying feasible. In other cases the tops are too bushy and full of branches. Effective spraying can never be done unless thorough pruning is annually practiced. Beyond a doubt, insufficient pruning has been a leading cause of failures.

The final, and perhaps most important difficulty, is the attitude of the fruit growers themselves. Because some have failed in their fight against the scale, many believe it is useless to try. The chief difficulty, which is really fundamental, lies in the fact that a majority of the orchardists failed to recognize the scale when it entered their orchards, or neglected to fight it till the insect became well established.

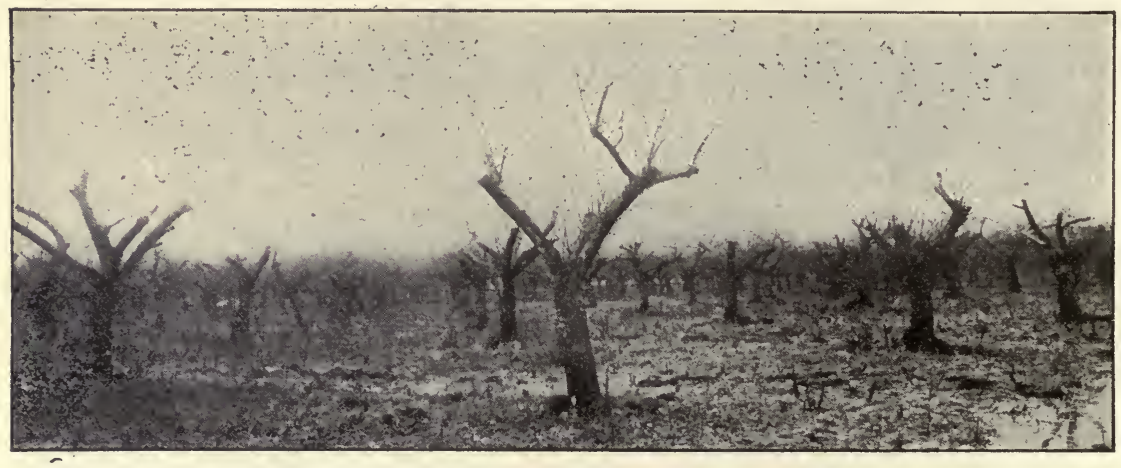

Fig. 36.-Excessive pruning of scale-infested trees. Note renewal of tops now free of scale. In orchard of Willard Hopkins, Youngstown

Just how the scale made its advent into the county is not known. Some assert that it was brought by birds from Canadian orchards, and others affirm that it was introduced on nursery stock shipped in from the South Atlantic states. Mr. T. Greiner, of La Salle, says that he had scale as early as 1899; and in Youngstown and Lewiston the insect has been familiar for at least six years. In their efforts to control the pest, some of the more progressive orchardists have tried all the recommended insecticides and caustics, such as lime and sulphur, crude oil, Scalecide, and kerosene emulsion. A few of the growers have given more attention to pruning than to spraying. A thinning-out of the tree top, and a reduction of the shoot system, followed by careful spraying, has proved the best method of control. Excessive pruning, amounting to a removal of nearly the entire tree top and leaving only a few main branches three to four feet in length, has been tried in Willard Hopkins' orchard. See Fig. 36. 
A few other interesting observations were made in this connection during the summer of 1907 , and may be recorded here as worthy of some attention:

Some varieties suffer more than others from the scale. Greenings and Baldwins appear to be most subject to scale, while Russets, Tolman, Oldenburg (Duchess), and Ben Davis suffer much less. This may be due to a difference in the character of the bark.

Trees in the central part of an orchard suffer more than those near the outside, due perhaps to the better winter protection to the scale. Trees in the centre of an orchard are a little less exposed to cold and drying winds and other adversities of the winter season.

Trees in a tilled orchard are injured more than those in a sod orchard; the more rapid growth and softer tissue in the tilled orchard may be advantageous to the scale.

Early-maturing varieties usually carry a smaller number of scales on the fruit.

Scale is always much worse where the pruning is insufficient.

Low heads and open top retard the spread of the scale on individual trees.*

The apple scab, which has been so troublesome -in apple districts generally, and especially in Wayne and Orleans counties, has not been serious the last few years in Niagara County. The scarcity of this fungus, and the consequent small loss from it, are probably due to the exceedingly dry weather in the summers of 1906 and 1907.

The collar rot, observed in many orchards in Wayne and Orleans counties, is not of infrequent occurrence in Niagara. Observations of the distribution of this disease tend to confirm earlier studies, namely, that it is confined largely to poorly drained land. It is important, however, to note that the rot in Niagara County is more frequent on Baldwins and Greenings than was formerly supposed. And this suggests that this disease is oftener associated with poorly drained soil than with particular varieties of apples.

* The San José scale has long been studied at the New York Agricultural Experiment Station at Geneva, and those interested should address that Station for bulletins on this subject. 
XII. Principal Enemies of the Apple in I905, igo6 and ig07

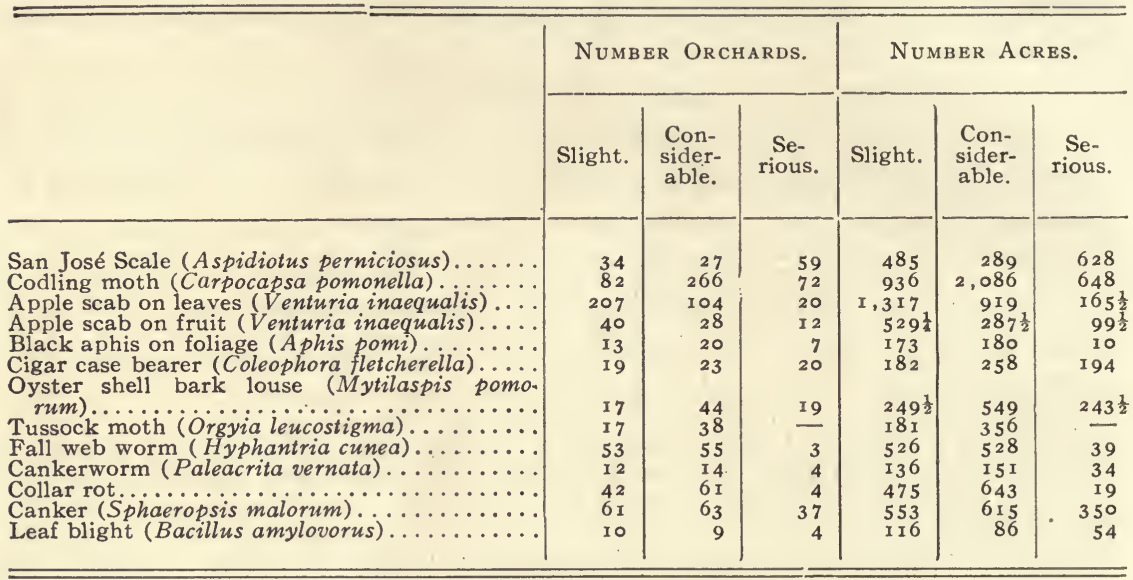

An additional list of enemies of lesser importance, and not especially troublesome except in unsprayed orchards, is here appended: woolly aphis, tent caterpillar, red spider, leaf roller, leaf miner, plum scale (Lecanium sp.), .bud moth, leaf hopper, curculio, borer, cottony scale, blister mite.

\section{SPRAYING}

Methods of spraying.-About four-fifths of the orchards are generally sprayed. Nineteen per cent were seldom or never sprayed, while $6.8 \%$ which were annually sprayed in the past were not sprayed in 1905. Approximately the same percentages hold with respect to acres. If one were to exclude the scale-infested area, a different showing would be made; for of those who do spray, more applications of some kind are given since an extra one is added for scale. But on the other hand, a number of otherwise good orchards are given up to the scale.

The records show that ten different kinds or combinations of spray mixtures have been used. Experimental solutions for the scale have increased this number by one-half. Several of these have been tried, however, in only a few orchards. Paris green and Bordeaux mixture ranks first, and second to this are prepared mixtures. Paris green has seldom been used alone. 
XIII. SPRAYING IN 1905

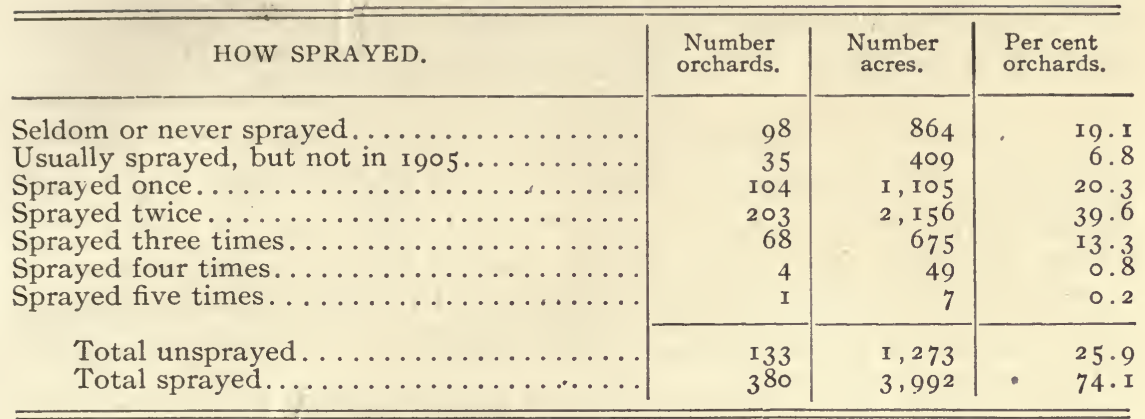

XIV. Kinds of Sprays USEd in 1905

\begin{tabular}{|c|c|c|c|}
\hline TREATMENT. & $\begin{array}{l}\text { Number } \\
\text { orchards. }\end{array}$ & $\begin{array}{l}\text { Number } \\
\text { acres. }\end{array}$ & $\begin{array}{l}\text { Per cent } \\
\text { orchards. }\end{array}$ \\
\hline Paris green and Bordeaux mixture........ & 221 & 2,230 & $57 \cdot 3$ \\
\hline Arsenic and Bordeaux mixture............ & 3 & 23 & 0.8 \\
\hline 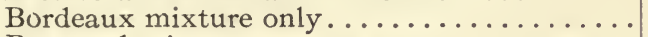 & 16 & 166 & $4 . I$ \\
\hline 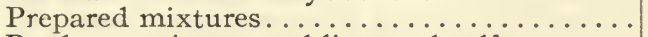 & IOI & 974 & 26.2 \\
\hline Bordeaux mixture and lime and sulfur...... & I9 & 197 & $4 \cdot 9$ \\
\hline 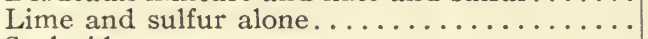 & Io & 99 & 2.6 \\
\hline Scalecide.................... & 2 & I9 & 0.5 \\
\hline Crude $0 i 1 . \ldots \ldots \ldots \ldots \ldots \ldots \ldots \ldots \ldots \ldots$ & Io & 200 & 2.6 \\
\hline Kerosene emulsion $\ldots \ldots \ldots \ldots \ldots \ldots \ldots \ldots$ & 2 & I 6 & 0.5 \\
\hline 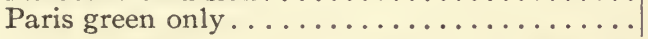 & 2 & 10 & 0.5 \\
\hline
\end{tabular}

How spraying affects yields and incomes. - The best answer to this question may be obtained by referring to the tables on this subject. Two computations were made on this point, one including all orchards within the survey and the other only well-cared-for orchards. The first table shows that the greatest yield follows from three sprayings, although there was a small gain in average income in favor of four sprayings. It is interesting as well as instructive to note the rising scale of average incomes in passing from the unsprayed group to that of four sprayings. This scale holds good for both tables.

XV. Spraying and Yield and Income per Acre, 1905. All Orchards INCLUDED

\begin{tabular}{|c|c|c|c|c|}
\hline HOW SPRAYED. & $\begin{array}{l}\text { Number } \\
\text { orchards. }\end{array}$ & $\begin{array}{l}\text { Number } \\
\text { acres. }\end{array}$ & $\begin{array}{l}\text { Average } \\
\text { yield. }\end{array}$ & $\begin{array}{l}\text { Average } \\
\text { income. }\end{array}$ \\
\hline Unsprayed...... & 99 & $I, 07 \mathrm{I}$ & $26 I$ & $\$ 45$ \\
\hline Sprayed once.... & 74 & 737 & 364 & 93 \\
\hline Sprayed twice......... & 162 & $\mathrm{I}, 778$ & $5 \circ 9$ & IOI \\
\hline Sprayed three times.......... & 63 & 526 & 577 & I 7 I \\
\hline Sprayed four times.......... & 5 & 76 & 390 & 183 \\
\hline
\end{tabular}


XVI. Spraying and Yield and Income per Acre, ig05. Orchards All Well Cared For

\begin{tabular}{|c|c|c|c|c|c|c|}
\hline HOW SPRAYED. & $\begin{array}{l}\text { Number } \\
\text { orchards. }\end{array}$ & $\begin{array}{l}\text { Number } \\
\text { acres. }\end{array}$ & $\begin{array}{c}\text { Average } \\
\text { yield. }\end{array}$ & $\begin{array}{l}\text { Number } \\
\text { orchards.* }\end{array}$ & $\begin{array}{l}\text { Number } \\
\text { acres.* }\end{array}$ & $\begin{array}{l}\text { Average } \\
\text { income. }\end{array}$ \\
\hline 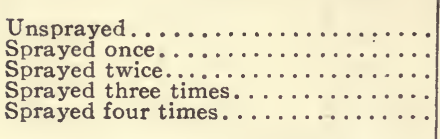 & $\begin{array}{r}57 \\
40 \\
8 \mathrm{r} \\
40 \\
3\end{array}$ & $\begin{array}{r}720 \\
368 \\
753 \\
425 \\
43\end{array}$ & $\begin{array}{l}266 \\
353 \\
422 \\
440 \\
285\end{array}$ & $\begin{array}{r}63 \\
48 \\
82 \\
40 \\
3\end{array}$ & $\begin{array}{r}810 \\
488 \\
758 \\
425 \\
43\end{array}$ & $\begin{array}{l}\$ 95 \\
146 \\
147 \\
201 \\
226\end{array}$ \\
\hline
\end{tabular}

* The computations for average income were based on a larger number of orchards than were those for average yield, hence the repetition of these headings.

It is interesting in this connection to note the results as computed for Orleans County (Bull. No. 229), hence tables and comments are printed herewith :

"Relation of spraying to yields and prices.-The first table below shows that the sprayed orchards give a much higher yield and income per acre than the unsprayed. The difference in income is due to the larger yield, larger percentage of the crop barreled and higher price per barrel. It will be seen that those sprayed three times gave 3I per cent larger yield and 5I per cent larger income than those not sprayed.

Spraying and Yield and Income per Acre, Orleans Co., igo4

\begin{tabular}{|c|c|c|c|c|c|c|c|}
\hline \multirow{2}{*}{ HOW SPRAYED. } & \multicolumn{3}{|c|}{ YIELDS. } & \multirow{2}{*}{$\begin{array}{l}\text { Per } \\
\text { cent } \\
\text { of crop } \\
\text { bar- } \\
\text { reled. }\end{array}$} & \multicolumn{3}{|c|}{ INCOMES. } \\
\hline & $\begin{array}{l}\text { Number } \\
\text { orchards. }\end{array}$ & $\begin{array}{l}\text { Number } \\
\text { acres. }\end{array}$ & $\begin{array}{c}\text { Average } \\
\text { yield. }\end{array}$ & & $\begin{array}{l}\text { Number } \\
\text { orchards. }\end{array}$ & $\begin{array}{c}\text { Number } \\
\text { acres. }\end{array}$ & $\begin{array}{l}\text { Average } \\
\text { income. }\end{array}$ \\
\hline 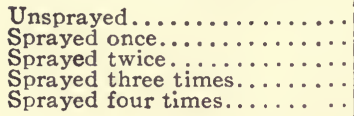 & $\begin{array}{r}100 \\
49 \\
90 \\
40 \\
6\end{array}$ & $\begin{array}{l}9 \times 7 \frac{1}{2} \\
504 \\
921 \frac{1}{2} \\
426 \\
43\end{array}$ & $\begin{array}{l}245 \\
307 \\
343 \\
322 \\
569\end{array}$ & $\begin{array}{l}71 \\
71 \\
75 \\
83 \\
77\end{array}$ & $\begin{array}{r}94 \\
46 \\
84 \\
37 \\
6\end{array}$ & $\begin{array}{l}86 \mathrm{I}^{\frac{1}{2}} \\
468 \\
864 \frac{1}{2} \\
406 \\
43\end{array}$ & $\begin{array}{l}\$ 92 \\
116 \\
1<7 \\
139 \\
211\end{array}$ \\
\hline
\end{tabular}

Spraying and Yield and Income per Acre, Orleans Co., Ig04. Orchards All Well Cared For

\begin{tabular}{|c|c|c|c|c|c|c|c|}
\hline \multirow{2}{*}{ HOW SPRAYED. } & \multicolumn{3}{|c|}{ YIELDS. } & \multirow{2}{*}{$\begin{array}{c}\text { Per } \\
\text { cent } \\
\text { of crop } \\
\text { bar- } \\
\text { reled. }\end{array}$} & \multicolumn{3}{|c|}{ INCOMES. } \\
\hline & $\begin{array}{c}\text { Number } \\
\text { orchards. }\end{array}$ & $\begin{array}{c}\text { Number } \\
\text { acres. }\end{array}$ & $\begin{array}{c}\text { Average } \\
\text { yield. }\end{array}$ & & $\begin{array}{l}\text { Numbe } \\
\text { orchards. }\end{array}$ & $\begin{array}{c}\text { Number } \\
\text { acres. }\end{array}$ & $\begin{array}{l}\text { A verage } \\
\text { income. }\end{array}$ \\
\hline $\begin{array}{l}\text { Unsprayed........... } \\
\text { Sprayed once........ } \\
\text { Sprayed twice. } \\
\text { Sprayed three times... } \\
\text { Sprayed four times.. }\end{array}$ & $\begin{array}{r}43 \\
33 \\
70 \\
27 \\
6\end{array}$ & $\begin{array}{c}381 \\
352 \\
701 \\
247 \frac{1}{2} \\
43\end{array}$ & $\begin{array}{l}328 \\
346 \\
374 \\
414 \\
569\end{array}$ & $\begin{array}{l}66 \\
74 \\
78 \\
87 \\
77 \\
\end{array}$ & $\begin{array}{r}54 \\
30 \\
64 \\
25 \\
6\end{array}$ & $\begin{array}{l}449 \frac{1}{2} \\
316 \\
644 \\
236 \frac{1}{2} \\
43\end{array}$ & $\begin{array}{r}\$ 103 \\
139 \\
143 \\
184 \\
211\end{array}$ \\
\hline
\end{tabular}


"A part of the difference in yield and income is due to other factors. The unsprayed orchards are likely to be somewhat neglected in other respects. To eliminate this factor, another classification was made after all neglected orchards were thrown out.

"The second table includes only those orchards that are fairly well cared for. They are not badly diseased or damaged from any cause. This shows a marked difference in the percentage of the crop barreled and in average yield and income, the average income per acre being: unsprayed, \$IO3; sprayed once, \$I39; sprayed twice, \$I43; sprayed three times, \$184. Allowing for the cost of the extra barrels required, for the cost of spraying and for a possible difference due to other causes than spraying, there is certainly enough difference left to give a large profit from the practice."

Spraying for the scab.- Spraying influences in a very materiai way the character of the crop and the amount of income. As the writer has previously noted, the summers of 1906 and 1907 were so dry that very little scab developed, and for this reason no computation in Niagara County was made to show the relation of scab to income. In view of this fact it seems well to publish the table formulated for Orleans County. It will be seen from this table that the greatest income comes where there is little scab. For example, associate $0-5$ per cent scab with an average income per acre of $\$ 143$, and contrast this with $76-100$ per cent scab with an average income per acre of $\$ 88$.

XVII. Relation of Scab to Income and Yields, Orleans Co., Igo4

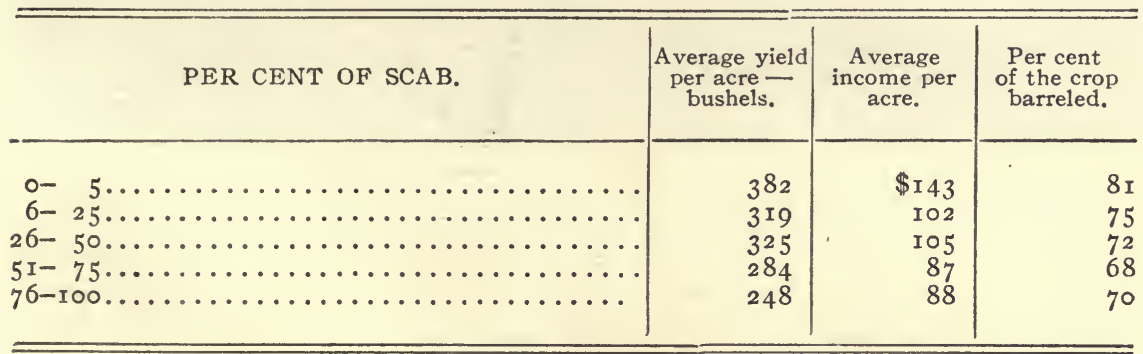

To control the scab, spray with Bordeaux mixture $3-3-50$ at the periods indicated on page 309 for codling moth.

Spraying for scale.- Spraying for San José scale has not been very generally practiced, and because of this fact the insect is gaining ground every year. The infested area extends from La Salle to Niagara Falls, throtgh Lewiston and Youngstown to Wilson, and includes a few orchards in Olcott and Lockport. In this area over seventy-five per 
cent of the orchards are more or less infested. The records show that within these bounds only forty-three orchards have been sprayed with solutions to kill the scale. Lime and sulfur has been used more than any other spray, although Scalecide and crude oil have been tried with some degree of success in about one-third of the orchards. Observations, however, tend to show that lime and sulfur should be adopted

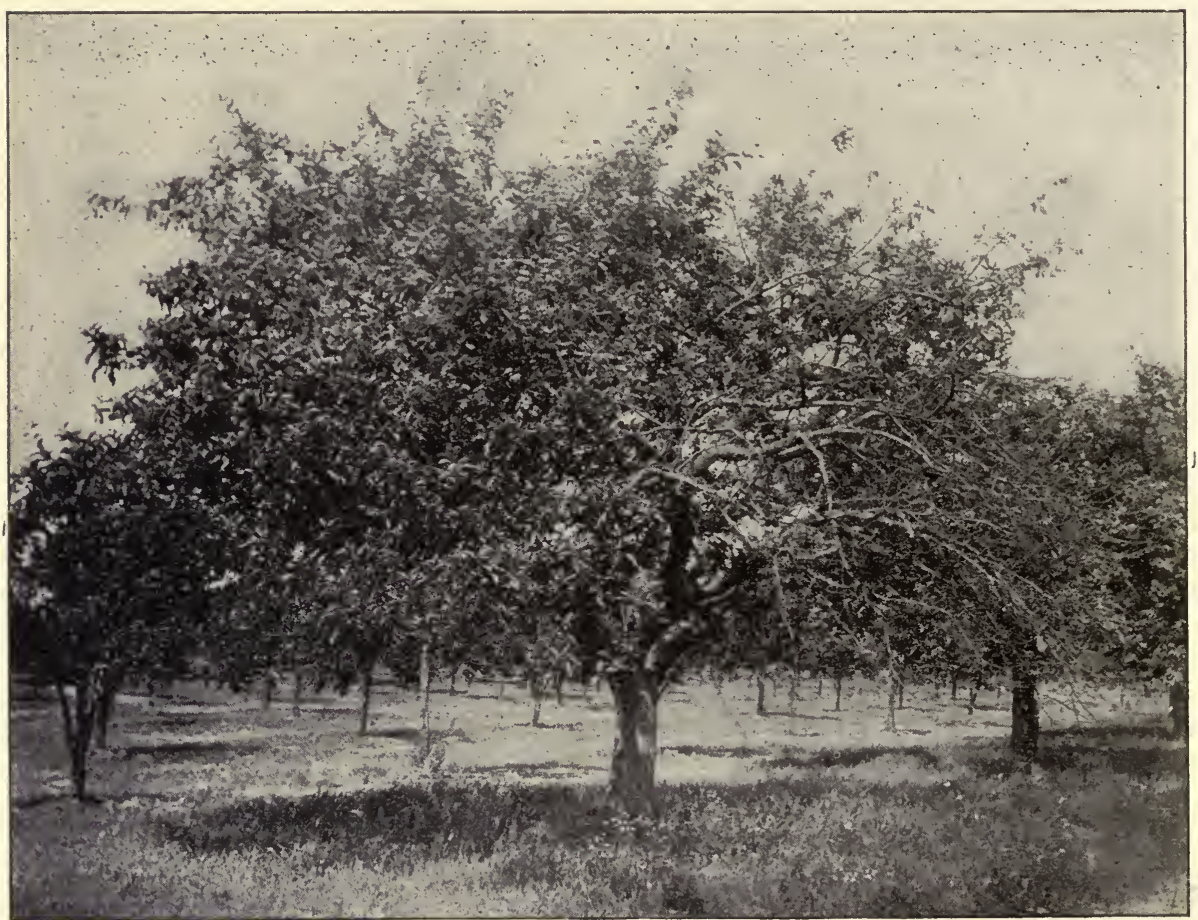

Fig. 37.- Lime and sulfur, an efjective spray for San José scale. Left side of tree sprayed, right side unsprayed. In orchard of Ermon Shippey, Youngstown

as the standard spray for scale. The formula for lime and sulfur now recommended for use is:

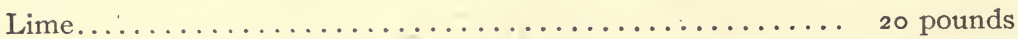

Sulfur (flour or flowers) $\ldots \ldots \ldots \ldots \ldots \ldots \ldots \ldots \ldots \ldots \ldots \ldots \ldots$ I 5 pounds

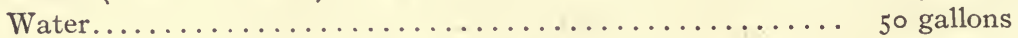

The preparation of this mixture involves careful attention to several particulars. The essentials briefly stated are as follows: Take the total quantity of sulfur to be used and make a thick paste with water. Heat in a cooking receptacle about one-third of the quantity of water required. When this water is hot, add all the lime and all the sulfur 
paste. Stir the solution while it is cooking. When the lime has slaked, add another third of hot water. Boil for fifty minutes, then strain the wash into the spray tank, and finally add the last third of water. The last addition of water may be hot or cold, preferably hot.

The kind of apparatus employed in cooking is immaterial, but it should be suitable, convenient and economical. The time of application of this spray is important. Lime and sulfur washes may be applied in the fall as soon as the trees have become dormant, and after the leaves have fallen. Experiments in different parts of the country indicate, however, that the best results follow application in spring just before the growth of the tree begins. It is a fungicide as well as an insect-killer. More recent experience has demonstrated that lime-sulfur in self-boiled form and in the manufactured proprietory mixture may be used satisfactorily as a summer spray when properly diluted. In the case of the concentrated manufactured mixture it should test 32 degrees by the Beaumé hydrometer and then be diluted by adding 30 parts of water to I part of concentrate.

Controlling codling moth.-A study of Table XI shows that the codling moth was found to be causing slight injury in 82 orchards comprising 936 acres, considerable injury in 266 orchards covering 2,086 acres, and serious injury in 72 orchards embracing 648 acres. This means that this insect is far too numerous and injurious for successful fruit-growing. The approved methods of controlling the codling moth may be classed under five headings.

I. Spraying. Observations throughout the county tend to show that more attention must be given to the time and manner of spraying. Two sprayings when properly done are sufficient for the codling moth.

(a) Immediately after the blossoms fall.

(b) Eight to twelve days after the second spraying.

The first application is very important. If the insecticide is thoroughly driven into the calyx cup at this time greater destruction of the larvae is insured.

Some fruit growers have followed these directions explicitly, and yet suffer from this pest. This leads naturally to the second feature of spraying, namely, the manner of application. It is a well-established fact that nearly three-fourths of the codling worms enter the apple through the calyx. It is therefore of utmost importance that the calyx cavity be well filled with poison so that the first meal of the young worm shall be his last. In order to fill the calyx cavity, the spray should be applied from four sides of each tree. This may be done by placing the spray wagon in. the open space between four trees and turning the hose 
toward each of the four trees. This will insure the thorough spraying of every branch from the proper direction. Use a nozzle which delivers a rather coarse spray of great penetration, and attach it to the extension rod with a brass elbow. Maintain a pressure of 125 to I 50 lbs. if possible.

2. Some birds are useful in combating codling moth. Woodpeckers and nuthatches are specially helpful, and their presence should be encouraged. In winter these birds pick the larvae, which is the winter form of codling moth, from the bark of trees, and thus destroy many

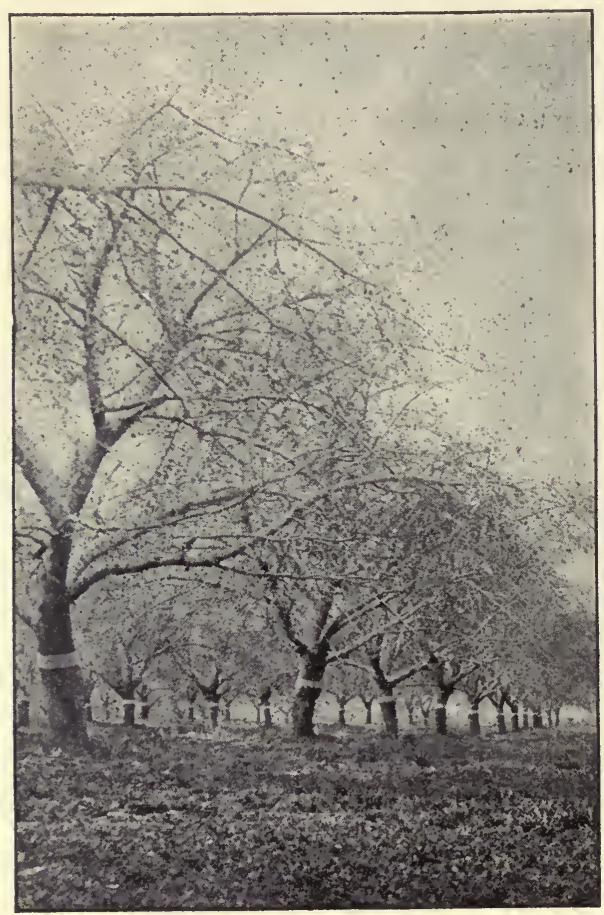

FIG. 38.-Trees banded with burlap to catch the codling moth as it climbs the trunk in late summer to form cocoons for winter of these insects.

3. Thorough scraping of the bark of trees will expose many wintering larvae, and aid in their control.

4. Gather and destroy all windfalls and wormy fruit. Sheep or hogs can do much of this work.

5. Use burlap bands on the tree trunks. Kill all insects under them every ten days from July Ist to August Ist, and once again later before winter.

\section{PRUNING}

The following table shows the facts with respect to pruning. In $66.7 \%$ of the orchards compared as to character of work, the pruning is good or fair, in $25.3 \%$ it is poor or carelessly done, and in $8 \%$ no pruning is done.

With respect to the frequency of pruning, it may be seen that over one-half, or $54.6 \%$ of the orchards compared as to this factor, are pruned every year; $22.6 \%$ are pruned on alternate years, $7.7 \%$ are pruned every third year, and I $_{5.1 \%}$ are not pruned at any regular interval.

A third classification of results shows that in $65.9 \%$ of the orchards thus compared, the tops are left too dense; in $34.2 \%$ the tops are too high. 
Some of the essential points in pruning were given in Bulletin 226. The first four here given are transcribed from that publication.

I. The branches should be cut close to the main limb.

2. Large limbs should not be removed unless necessary.

3. Paint should be used on all large wounds, and renewed yearly until the wounds are healed.

4. Pruning should be done every year rather than give an occasional thorough trimming.

5. Thinning out the tops should be practiced regularly.

6. Do not continually prune off the lowest branches.

XVIII. Data on Pruning

\begin{tabular}{|c|c|c|c|}
\hline CHARACTER OF WORK. & $\begin{array}{l}\text { Number } \\
\text { orchards: }\end{array}$ & $\begin{array}{l}\text { Number } \\
\text { acres. }\end{array}$ & $\begin{array}{l}\text { Per cent } \\
\text { orchards. }\end{array}$ \\
\hline \multicolumn{4}{|l|}{ Character of work: } \\
\hline Good................. & I 56 & $\mathrm{I}, 570$ & 30.6 \\
\hline Fair $\ldots \ldots \ldots \ldots \ldots \ldots \ldots \ldots \ldots$ & I 84 & 1,772 & 36.1 \\
\hline Poor or neglected $\ldots \ldots \ldots \ldots \ldots \ldots \ldots \ldots$ & 129 & I, 299 & $25 \cdot 3$ \\
\hline None.............................. & 4 I & 483 & 8.0 \\
\hline \multicolumn{4}{|l|}{ Frequency of pruning: } \\
\hline Every year................... & 256 & 2,766 & 54.6 \\
\hline 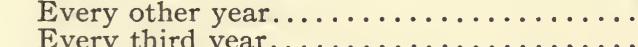 & 106 & I, 230 & 22.6 \\
\hline 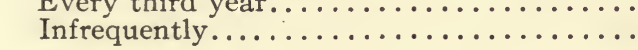 & $\begin{array}{l}30 \\
71\end{array}$ & $\begin{array}{l}380 \\
875\end{array}$ & $\begin{array}{r}7.7 \\
15.1\end{array}$ \\
\hline \multicolumn{4}{|l|}{ Other features of pruning: } \\
\hline 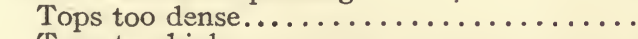 & 54 & 468 & $65 \cdot 9$ \\
\hline 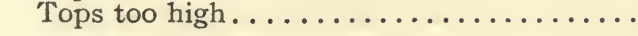 & 28 & 279 & $34 \cdot 2$ \\
\hline
\end{tabular}

NUMBER OF TREES PER ACRE

There has been great variation in the number of trees planted to the acre. A few orchardists have planted as close as $22 \times 22$ feet, some have put the trees as far apart as $50 \times 50$, but a majority have planted at $36 \times 36$ or $40 \times 40$. The favorite distance has been $36 \times 36$. This means 33.6 trees to the acre, a number which is far too many to fit in with the best methods of modern orchard management. A glance at Table XIX shows that $47.9 \%$ of the area has been planted at $36 \times 36$ to $40 \times 40$ feet apart. In young orchards set since 1890 , more attention has been given to placing the trees at proper distances. None of the newer orchards contained trees nearer than $3 \mathrm{I} \times 3 \mathrm{I}$, while the largest numbers were set at $35 \times 35$ or $36 \times 36$. It would be much better if all the trees were set 40 to 45 feet apart. 
The distance between trees affects in an important way the thoroughness of spraying and the character of the fruit. When trees are close together, it is often difficult to spray from all sides, and frequently impossible from the most important side of the tree. Great losses from the effects of scale and codling moth have been sustained because of crowded trees. More room between trees will facilitate spraying and tend to insure better quality of fruit.

XIX. Distance Between Trees

\begin{tabular}{|c|c|c|c|c|c|c|c|}
\hline \multirow{2}{*}{ DISTANCE APART. } & \multicolumn{3}{|c|}{ Trees Set Before 1890.} & \multicolumn{4}{|c|}{ Trees Set Since 1890.} \\
\hline & $\begin{array}{l}\text { Number } \\
\text { orchards. }\end{array}$ & $\begin{array}{c}\text { Number } \\
\text { acres. }\end{array}$ & $\begin{array}{c}\text { Percent } \\
\text { acres. }\end{array}$ & $\begin{array}{l}\text { Number } \\
\text { orchards. }\end{array}$ & $\begin{array}{c}\text { Nun } \\
\text { acr }\end{array}$ & $\begin{array}{l}\text { nber } \\
\text { res. }\end{array}$ & $\begin{array}{c}\text { Per cent } \\
\text { acres. }\end{array}$ \\
\hline \multirow[t]{2}{*}{ 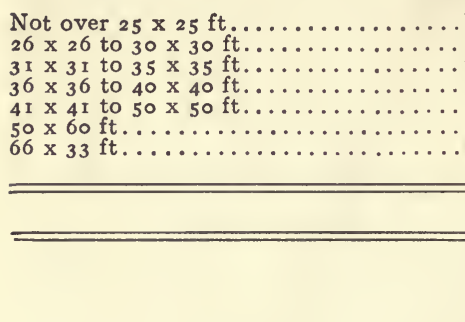 } & $\begin{array}{r}17 \\
122 \\
135 \\
221 \\
12 \\
4 \\
6\end{array}$ & $\begin{array}{l}171 \\
1,041 \frac{1}{2} \\
1,151 \frac{1}{2} \\
2,3772 \\
144 \\
28 \\
52\end{array}$ & $\begin{array}{r}3.4 \\
21.0 \\
23.2 \\
47.9 \\
2.9 \\
.6 \\
1.1\end{array}$ & $\begin{array}{l}- \\
9 \\
3 \\
4 \\
-\end{array}$ & & $\begin{array}{l}\text { 三 } \\
91 \\
12 \\
59 \\
\end{array}$ & $\begin{array}{r}\text { 二 } \\
56.2 \\
7.4 \\
36.4 \\
=\end{array}$ \\
\hline & & & & \multicolumn{2}{|c|}{$\begin{array}{c}\text { Trees set } \\
\text { before I } 890 .\end{array}$} & \multicolumn{2}{|c|}{$\begin{array}{c}\text { Trees set } \\
\text { since } 1899^{\circ}\end{array}$} \\
\hline \multicolumn{4}{|c|}{ 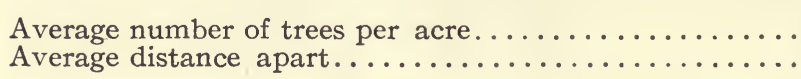 } & \multicolumn{2}{|c|}{$\begin{array}{l}38.2 \\
33.8\end{array}$} & & $\begin{array}{l}36.4 \\
34.6\end{array}$ \\
\hline
\end{tabular}

\section{RENTED ORCHARDS}

Only thirteen and three-tenths per cent of the orchards are rented. Of this number almost one-half, or forty-six and two-tenths per cent, are rented for five years or more. The average period of tenure is four years. This investigation of rented orchards, and the period of rental, gives a much better showing than was made from computations in Wayne or Orleans County, and represents a condition which is very much as it should be.

XX. Orchards Rented and Orchards Worked by Owner

\begin{tabular}{|c|c|c|c|}
\hline TENURE. & $\begin{array}{l}\text { Number } \\
\text { orchards. }\end{array}$ & $\begin{array}{l}\text { Number } \\
\text { acres. }\end{array}$ & $\begin{array}{l}\text { Per cent } \\
\text { orchards. }\end{array}$ \\
\hline $\begin{array}{l}\text { Rented } \ldots \ldots \ldots \ldots \ldots \\
\text { Worked by owner......... }\end{array}$ & $\begin{array}{r}78 \\
5 \circ 7\end{array}$ & $\begin{array}{r}673 \\
5,360\end{array}$ & $\begin{array}{l}\text { I } 3 \cdot 3 \\
86.7\end{array}$ \\
\hline
\end{tabular}


XXI. Years of TENURE

\section{YEARS OF TENURE.}

One year.

Two years.

Three and four years

Five or more years.

$\begin{gathered}\text { Number } \\ \text { orchards. }\end{gathered}$
I 5
I 4
I 3
36

\section{Number acres.}

\section{YIELDS, PRICES AND -MARKETS, AND INCOME}

Yields.-Four tables are presented herewith which give the essentials with respect to yields. The table on yields for the entire county is only approximate, as is that on average yields per tree. All yields are much reduced because of the scale in the western part of the county.

XXII. Approximate Total Yield in Bushels for Entire County I 889 (U. S. Census Report)

623,204 I 899 (U. S. Census Report)......................... I,42I,796

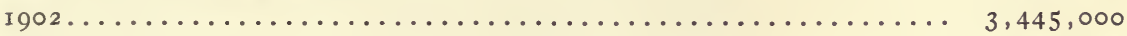

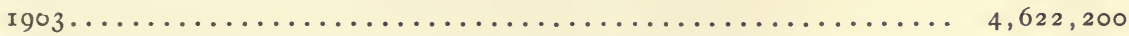

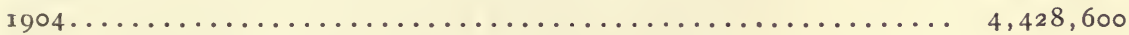

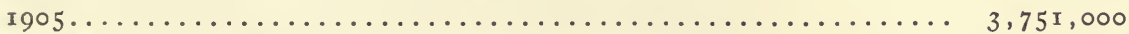

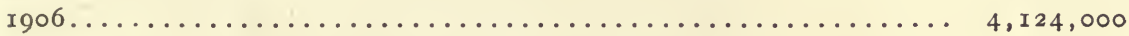

The estimates for the last five years are only approximate.

XXIII. Average Yield per Acre in Bushels

\begin{tabular}{|c|c|c|c|}
\hline YEAR. & $\begin{array}{l}\text { Number } \\
\text { orchards. }\end{array}$ & $\begin{array}{l}\text { Number } \\
\text { acres. }\end{array}$ & $\begin{array}{l}\text { Average } \\
\text { yield. }\end{array}$ \\
\hline 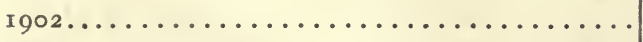 & I 25 & I, 4 I 5 & 236 \\
\hline 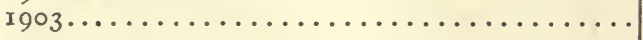 & 273 & 2,736 & I97 \\
\hline 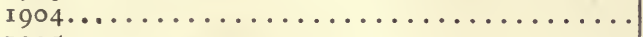 & 459 & 4,321 & I95 \\
\hline 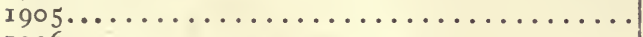 & 372 & 4,152 & I 55 \\
\hline 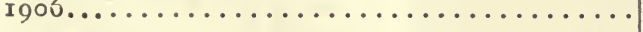 & I 73 & $2,03 I$ & I 79 \\
\hline
\end{tabular}

The average yield for the five-year period is 192.4 bushels, which is 29 bushels less than was found for Orleans County, and 34 more than was found for Wayne County. 
XXIV. Average Yield per Tree

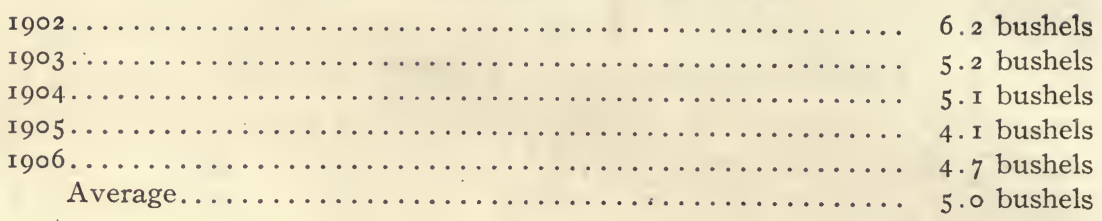

These results were obtained by dividing the average yields per acre ('Table XXII) by the average number of trees per acre, which is 38.2. This average yield per tree is two-tenths of a bushel more than was found for Orleans County, and is one and four-tenths more than in Wayne.

XXV. Classification of Yields

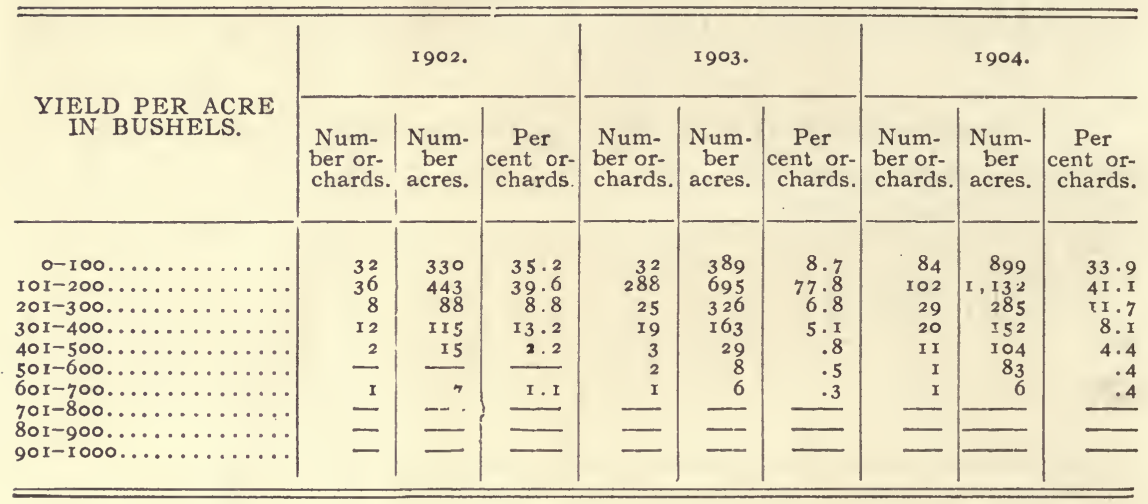

\section{Classification of Yields}

YIELD PER ACRE
IN BUSHELS.


Prices and markcts. - The tab.e given below shows the average prices for the crops as they were marketed for the different years. The averages for 1905 and 1906 were based on a smaller number of computations than for any of the other years; still they are representative for the county for those years.

XXVi. Average Price Paid to Grower

\begin{tabular}{|c|c|c|c|c|c|}
\hline HOW MARKETED. & 1902. & $\times 903$. & I 904. & 1905. & I906. \\
\hline $\begin{array}{l}\text { Price per barrel.... } \ldots \text { in bulk } \ldots \ldots \ldots \ldots \ldots \ldots \ldots \ldots \\
\text { Price per bushel sold } \ldots \ldots \ldots \ldots \ldots \\
\text { Price per roo pounds sold to dry } \ldots \ldots \ldots \ldots \ldots \ldots \\
\text { Price per roo pounds for cider } \ldots \ldots \ldots \ldots \ldots \ldots\end{array}$ & $\begin{array}{r}\$ 200 \\
18 \\
29 \\
\end{array}$ & $\begin{array}{r}\text { \$1 } 82 \\
35 \\
35 \\
\end{array}$ & $\begin{array}{r}\$ 232 \\
28 \\
30 \\
\end{array}$ & $\begin{array}{ll}\$ 2 & 18 \\
31 \\
42 \\
20 \\
20\end{array}$ & $\begin{array}{rr}\text { \$1 } 56 \\
27 \\
33 \\
24\end{array}$ \\
\hline
\end{tabular}

Niagara County apples go to a cosmopolitan market. Some find immediate markets in the large cities of the state, such as Buffalo,

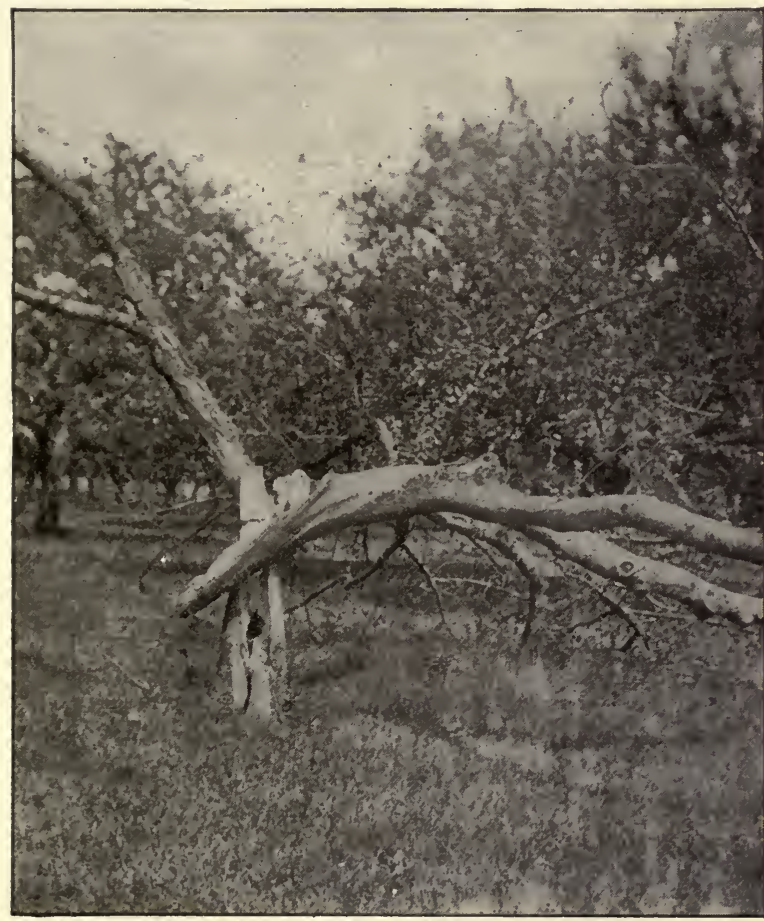

Fig. 39.- Result of a bad crotch. Three limbs were started from same place, and when heavy each has split off.
Rochester, and New York, but still larger quantities go to more general markets in the Middle West. A few growers store their fruit and retail in winter at Buffalo and Niagara Falls; but the bulk of the apples is sold to the highest bidding commission man. Very few growers reported any price for cider or vinegar apples. Such markets are not worth while.

Under normal conditions the bulk of apples in the county is handled in the apple barrel. Up to five years ago, the sorting table and the 
apple barrel were the characteristic features of the apple industry. But with the introduction and spread of the scale, important changes have occurred. Since 1902, the cider mill and the evaporator have come to the fore. In 1902, only .9\% of the apples went to the evaporator. In 1903, this had increased to $2.8 \%$; in 1904, it was still increasing, and had run up to about $7.3 \%$; while in 1905 , the evaporator claimed $34.1 \%$ of the crop. This seemed to be the climax, for in 1906, the evaporated portion had fallen to 27.I\%.

There have been three chief causes for the production of so much inferior fruit: The apple scab, the codling moth, and the San José scale. In 1905, there was considerable scab on apples, but since then there has been but little. There is considerable loss every year from codling moth. But the most potent factor is the scale, which is a prolific feeder of the evaporating factory.

Outside of the scale-infested area different conditions prevail. Take, for instance, the year of 1905, when our field notes were the most complete, and another aspect is presented. Our records for that year show that in the eastern part of the county the evaporator received only three per cent of the crop, whereas for the entire county in the same year thirty-four per cent went to the dry-house. Similar contrasts might be constructed for other years. The time seems ripe, then, for a fuller recognition of the importance of fighting the scale, and every effort should be made to destroy this pest. Every apple grower who allows scale to breed in his orchard should feel that he is not only injuring his own business, but helping to stigmatize the character of the whole county.

XXViI. Disposal of the Crop

\begin{tabular}{|c|c|c|c|c|c|c|}
\hline \multirow{2}{*}{ HOW MARKETED. } & \multicolumn{2}{|c|}{1902.} & \multicolumn{2}{|c|}{1903.} & \multicolumn{2}{|c|}{1904.} \\
\hline & Bushels. & Per cent. & Bushels. & Per cent. & Bushels. & Per cent. \\
\hline 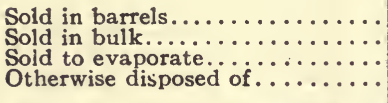 & $\begin{array}{r}188,692 \\
33,622 \\
2,050 \\
\end{array}$ & $\begin{array}{r}84.1 \\
15.0 \\
.9 \\
\end{array}$ & $\begin{array}{r}381,712 \\
90,606 \\
13,645 \\
500\end{array}$ & $\begin{aligned} 78.5 \\
18.6 \\
2.8 \\
.1\end{aligned}$ & $\begin{array}{r}419,890 \\
85,059 \\
39,726 \\
384\end{array}$ & $\begin{array}{r}77.0 \\
15.6 \\
7.3 \\
.1\end{array}$ \\
\hline
\end{tabular}




\begin{tabular}{|c|c|c|c|c|}
\hline \multirow{2}{*}{ HOW MARKETED. } & \multicolumn{2}{|c|}{1905.} & \multicolumn{2}{|c|}{ I 906.} \\
\hline & Bushels. & Per cent. & Bushels. & Per cent. \\
\hline 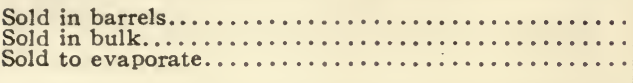 & $\begin{array}{r}125,043 \\
17,500 \\
73,788\end{array}$ & $\begin{array}{r}57.8 \\
8.1 \\
34.1\end{array}$ & $\begin{array}{r}183,419 \\
13,900 \\
73,183\end{array}$ & $\begin{array}{r}67.8 \\
5.1 \\
27.1\end{array}$ \\
\hline
\end{tabular}

Income per acre.- The information gathered on this point is displayed in two tables. One shows the average gross income per acre for each of the five years. The general average for the five-year period is $\$ 109.20$ per acre. This is $\$ 16$ less per acre than was found for Orleans County. The second classification shows how these incomes are distributed with reference to the number of orchards and number of acres under each group. The grower will find it interesting to study these tables with reference to his own orchard.

\section{Average Gross Income per Acre}

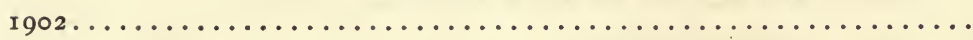

$\$ 112.00$

1903

129.00

I 904

98.00

1905

103.00

1906 .

104.00

General average for the five-year period

$\$ 109.20$

\section{Classification of Incomes}

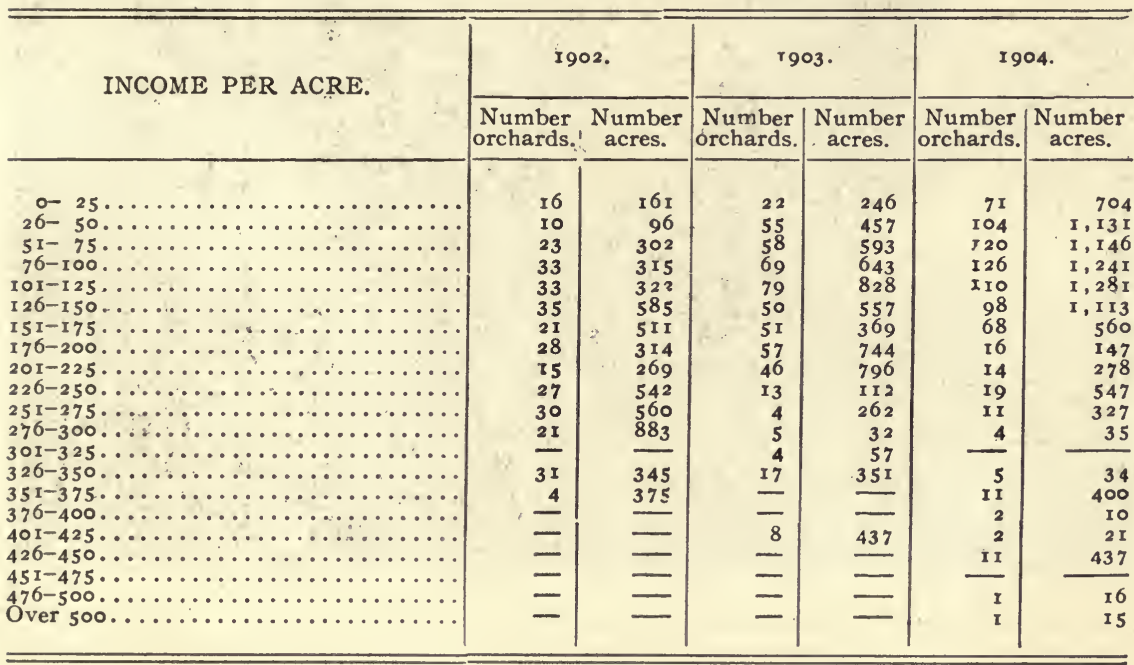


Classificition of InCOMES

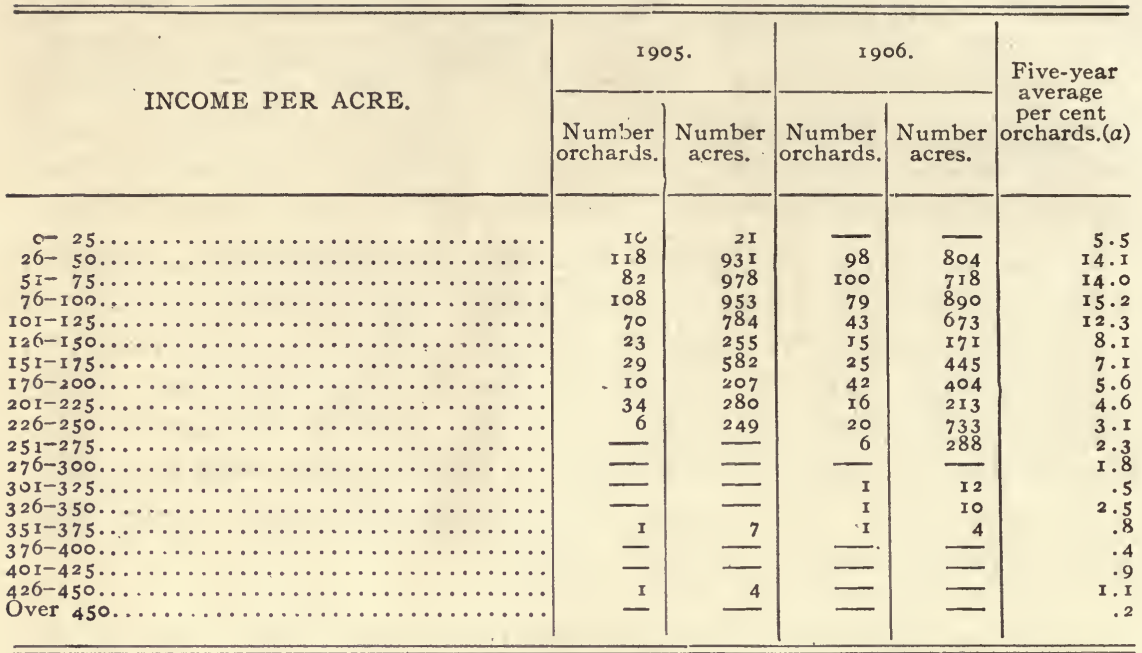

(a) Less than five years in a few cases.

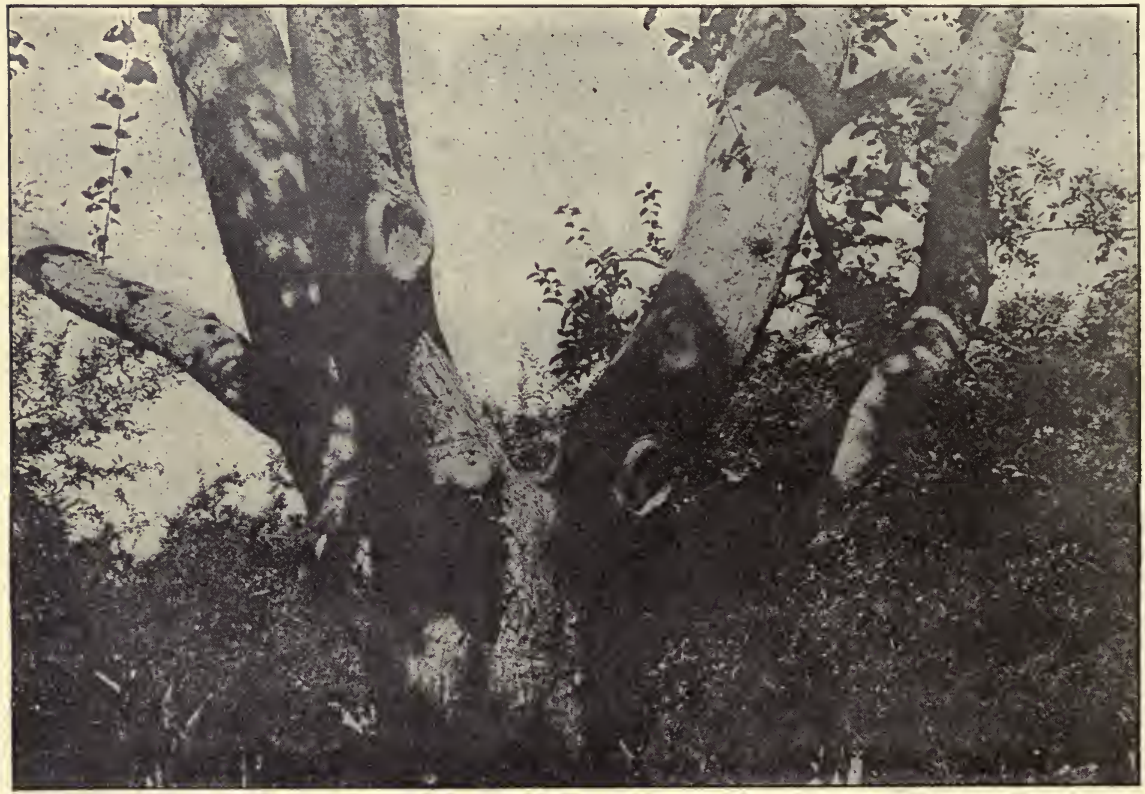

FIG. 40.-A sample of good pruning, showing the healing process well under way 


\section{SUMMARY}

Extent of the survey.- During the summers of 1905,1906 and 1907 , over $716^{*}$ orchards containing 6,000 acres were canvassed in Niagara County. There are approximately 24,200 acres set to apples. Representative districts all through the county were examined.

Age of the trees.-A majority of the orchards were planted thirty to forty-five years ago. Five and four-tenths per cent were set out before 1850, 8I.I per cent were planted between 1850 and I879, and I3.6 per cent since 1880 . During the past seven years, the scale has deterred many from planting orchards, but the decreased plantings began twentyseven years ago, and the acreage.has been on the decline since 1880 .

Soils.-The Dunkirk loam and the Dunkirk clay loam are the best soils for apple production. Clyde loam gives the lowest yields. Too little attention has been given to drainage, and much loss has been sustained because of this neglect.

Drainage.-Fifty-two and two-tenths per cent of the orchards have good drainage, about twenty-six per cent have fair drainage, and about eleven per cent have poor drainage. About eleven per cent have locally bad drainage. A little money spent in draining the orchard land would prove a good investment.

Fertilization.- Barnyard manure is used more than any other fertilizer. Sixty-one per cent of the orchards receive manure, about four per cent are given commercial fertilizer, and about twenty-two per cent are not fertilized at all. Cover-crops are used to the extent of nearly ten per cent.

Tillage.-Approximately fifty-one per cent of the orchards have been tilled for five or more years, and twenty-eight and nine-tenths per cent have been in sod for the same time. Five-year averages show larger yield and greater income for tilled than untilled orchards. The percentage of tilled orchards seems to be on the increase, for in 1905 fiftytwo per cent of the orchards were tilled. There are many sod orchards that are well cared for. Of the sod orchards, those not pastured have given the largest average yields. Where pasturing has been practiced, hog treatment has proved the best.

Enemies of the apple.- During the last six years the scale and codling moth have been the worst enemies of the apple. Collar rot is bad only in sections, and generally on poorly drained land. More attention must be given to spraying to insure good quality of fruit.

Spraying.-About four-fifths of the orchards are generally sprayed. The presence of the scale has made very little difference in spraying

* Includes 135 orchards not embraced in Table I on page 288 . 
practices, although it has increased the kinds of spray mixtures used. Very few of the scale-infested orchards have been treated with scalekilling mixtures. Paris green with Bordeaux has been most generally used. When averages are considered, there seems to be a definite relation between spraying and yield and income. However, this does not hold with four sprayings, probably because of other disturbing factors. Unsprayed orchards give an average yield of 26I bushels, with an average income of $\$ 45$ per acre. One spraying gives 364 bushels, and an income of $\$ 93$ per acre. Two sprayings yield 509 bushels, and give \$IOI. Three sprayings carry the yield to 577 bushels, and the income to $\$ 171$. The largest number of orchards and the greatest number of acres are given two sprayings per year. In well-cared-for orchards, the maximum yield comes with three sprayings; but the maximum income follows four sprayings.

Pruning. - In sixty-six and seven-tenths per cent of the orchards compared as to character of pruning, the pruning is good or fair, in twentyfive and three-tenths per cent it is poor or neglected, while in eight per cent no pruning is done. Effective and profitable spraying is impossible where insufficient pruning is done. More pruning and greater regularity of the work must be adopted in order to fight successfully the serious pests.

Distance between trees. - The average distance between trees is 338 feet. The favorite distance is $36 \times 36$. Nearly half of the orchards were set from $36 \times 36$ to $40 \times 40$. In forty-seven per cent of the orchards the trees are too close.

Rented orchards. - Very few orchards have been rented. Only thirteen and three-tenths per cent have been held by tenants during recent years, and of these forty-six and two-tenths per cent have been let out for at least five-year periods.

Yields. - The average yields per acre have been: I902, 236 bushels; I903, I97 bushels; 1904, I95 bushels; I905, I55 bushels; I906, I79 bushels. The average for the five years is 192.4 bushels.

Prices.-The average prices per barrel have been: 1902, \$2.00; I903, \$1.82; I904, \$2.32; 1905, \$2.18; I906, \$1.56.

Income per acre. - The average gross incomes per acre have been: 1902, \$112; I903, \$129; I904, \$98; 1905, \$103; 1906, \$104. The general average for the five years is $\$ 109.20$.

Varieties.-About thirty kinds of apples are grown in the county. Rhode Island Greening, Baldwin and Northern Spy are the chief varieties. Russets, King, Tolman, Twenty-ounce and Hubbardston, however, are grown to considerable extent. 


